Florida State University College of Law

Scholarship Repository

Scholarly Publications

Fall 2007

\title{
The Low Road to Cy Pres Reform: Principled Practice to Remove Dead Hand Control of Charitable Assets
}

Rob Atkinson

Follow this and additional works at: https://ir.law.fsu.edu/articles

Part of the Estates and Trusts Commons, and the Nonprofit Organizations Law Commons

\section{Recommended Citation}

Rob Atkinson, The Low Road to Cy Pres Reform: Principled Practice to Remove Dead Hand Control of Charitable Assets, 58 CASE WESTERN RES. L. REV. 97 (2007),

Available at: https://ir.law.fsu.edu/articles/395

This Article is brought to you for free and open access by Scholarship Repository. It has been accepted for inclusion in Scholarly Publications by an authorized administrator of Scholarship Repository. For more information, please contact efarrell@law.fsu.edu. 


\title{
THE LOW ROAD TO CY PRES REFORM: PRINCIPLED PRACTICE TO REMOVE DEAD HAND CONTROL OF CHARITABLE AsSETS
}

\author{
Rob Atkinson ${ }^{\dagger}$ \\ Ye tak' the high road, and I'll tak' the low road, and I'll get to \\ Scotland afore ye. \\ - The Bonnie, Bonnie Braes of Loch Lomond
}

\begin{abstract}
In recent decades many scholars have called for reduction of dead hand control of charitable assets. These scholars have recommended the "high road" to reform: sweeping, wholesale revision of legal doctrines by either courts or legislatures. These calls, for all their merit, have gone virtually unheeded. In the face of that apparent impasse, this article recommends a different route, a "low road," to reform: an immediately available set of strategies for removing dead hand control, strategies that can be deployed, in particular cases, right

† Ruden, McClosky, Smith, Schuster \& Russell Professor of Law, Florida State University. My particular thanks to Harvey Dale and Jill Manny, Director and Executive Director, respectively, of the National Program on Philanthropy and the Law at the New York University School of Law, for inviting me to present this paper as part of the Program's 2005 annual conference, on the general topic of Grasping the Nettle: Honoring Donor Intent and Avoiding the Dead Hand. They and the other conference participants offered insightful comments on my position; my official commentators, Rochelle Korman of Patterson, Belknap, Webb \& Tyler and Carlyn S. McCaffrey of Weil, Gotshal \& Magnes, were especially generous with their time and thoughtful with their comments. I owe another round of useful comments to the faculty of the University of Alabama School of Law, who were my very gracious hosts for the spring semester of 2006 and who invited me to present this paper in their workshop series. Florida State law students Jessica Slatten, Tanya Simpson, Brian Sites, Bernard O'Donnell, and Matthew Umbarger, and University of Alabama law student Nathan Lucas, provided invaluable research assistance.
\end{abstract}


now. The net effect of this piecemeal, practical approach should be to move us, albeit in small, incremental steps, around the impasse of dead hand doctrine toward the theoretically higher ground of freer, more fungible charitable assets and increased charitable autonomy.

INTRODUCTION: THE ProspeCt OF UNITING ACADEMIC THEORY AND ROUTINE PRACTICE TO FREE CHARITABLE ASSETS FROM DEAD HAND CONTROL

I. MAPPING THE ROADS TO REFORM OF DEAD HAND CONTROL. 104 A. The Separation of High Academic Theory from Principled Routine Practice... 104

B. Impasses on the High Road to Reform: The Failure of Traditional Legislative and Judicial Approaches 106

C. Opening a Low Road to Reform: Toward Collaboration Between High Academic Theory and Principled Routine

Practice. 108

II. THE DOCTRINE OF DEAD HAND CONTROL AND ITS ORTHODOX EXCEPTIONS 108

A. The Hypothetical Case: The Saga of Aunt Essie's Farm and Fortune 109

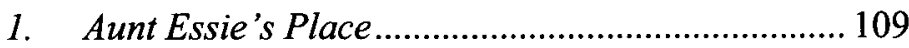

2. Aunt Essie's Passing ............................................ 110

3. The Advent of Wal-Mart ...................................... 111

B. The Dual Domain of the Dead Hand: Private and Charitable Assets......................................................... 112

1. Dead Hand Control Outside the Charitable Sector....

2. Dead Hand Control Inside the Charitable Sector. 130

3. Summary.............................................................. 140

III. THE LOW ROAD TO CY PRES REFORM ….............................. 141

A. Principled Practice ...................................................... 142

1. Charities' Acting Unilaterally.............................. 143

2. Charities' Acting with State Attorneys General .... 144

3. Charities' Buying Out Adverse Private Interests.. 148

4. Charities' Invoking Eminent Domain .................... 153

B. Unprincipled Practice .................................................. 161

1. Self-Indulgent Charitable Fiduciaries .................. 161

2. Imperialist State Attorneys General ..................... 162

3. Piratical State Legislatures................................ 163

C. Summary ................................................................... 164

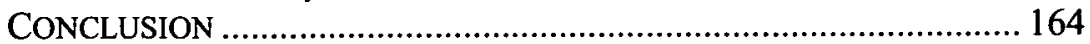




\section{INTRODUCTION: THE PROSPECT OF UNITING ACADEMIC THEORY AND ROUTINE PRACTICE TO FREE CHARITABLE ASSETS FROM DEAD HAND CONTROL}

Dead hand control of charitable assets is of immense practical and theoretical importance. On the theoretical side, at the deepest level and the broadest scope, concern about dead hand control merges with Jefferson's looming question about law itself: "whether, by the laws of nature, one generation . . . can, by any act of theirs, bind those which are to follow them?"1 The purpose of the law of charity, like that of the law writ large, is to provide public benefits-in constitutional terms, to promote the general welfare. Why should we, in charity any more than elsewhere in law, defer to the dead in determining the good of the living? ? $^{2}$

The stakes are equally high on the practical side. Take only the most salient example, contemporary changes in the delivery of health services, especially hospital care. We have seen a dramatic shift from predominantly charitable and public hospital ownership to predominantly for-profit ownership. ${ }^{3}$ Both fundamental human needs and vast amounts of social capital are at stake. ${ }^{4}$

1 Letter from Thomas Jefferson to Joseph C. Cabell (1814), in 1814 THE WrITINGS oF THOMAS JEFFERSON at 14:67 (Lipscomb \& Burgh eds., Mem. Ed. 1904).

2 I am not the first to note the parallels between issues of deferring to the dead in matters of law and philanthropy. See ROBERT H. BORK, DONOR INTENT: INTERPRETING THE FOUNDER'S VISION 3 (1993) ("The similarities between constitutional and philanthropic interpretation exist where the donor has either expressed intentions or engaged in activities during his life that give a tolerably clear idea of what things he intended or, at least, some things he did not intend.") Not surprisingly, perhaps, Prof. Bork takes the same decidedly originalist line in philanthropy as in law; that line is not mine in either philanthropy or in law. See Rob Atkinson, Reforming Cy Pres Reform, 44 HASTINGS L.J. 1111 (1993) (rejecting the originalist line in philanthropy); Rob Atkinson, Reviving the Roman Republic: Remembering the Gold Old Cause, 71 FORDHAM L. REV. 1187 (2003) (rejecting the originalist line in law).

3 Thomas Silk, Conversions of Tax-Exempt Nonprofit Organizations: Federal Tax Law and State Charitable Law Issues, 13 EXEMPT. ORG. TAX REV. 745, 745 (May 1996) ("a sectorshift is occurring: the provision of profitable health care activities is being shifted from the nonprofit sector to the for-profit sector" with an unprecedented scale and speed). See also Jill R. Horowitz \& Marion Fremont-Smith, The Common Law Power of the Legislature: Insurer Conversions and Charitable Funds, 83 THE MILBANK QUARTERLY 225, 226 (2005). Cf. Jill R. Horowitz, Does Nonprofit Ownership Matter?, 24 YALE J. REG. 139, 146 (2007) ("the net distribution of hospital types has not changed."). See also, Jill R. Horowitz, Why We Need the Independent Sector: The Behavior, Law, and Ethics of Not-For-Profit Hospitals, 50 U.C.L.A. L. REV. 1345, 1352 n.18 (2003) (same).

4 See Robert Boisture \& Douglas N. Varley, State Attorneys General's Legal Authority to Police the Sale of Nonprofit Hospitals and HMOs, 13 EXEMPT. ORG. TAX REV. 227, 227 (Feb. 1996) ("These [hospital conversions] promise to result in by far the largest redeployment of charitable assets in history, potentially involving tens of billions of dollars."). See also Horowitz, Why We Need the Independent Sector, supra note 3 (arguing for a continuing large role for nonprofits in hospital care as an essential human need); Horowitz, Does Nonprofit Ownership Matter?, supra note 3; David A. Hyman, Hospital Conversions: Fact, Fantasy, and Regulatory Follies, 23 J. CORP. L. 741, 743-746 (1998) (noting the "significance of these 
This raises several related questions that echo elsewhere in the charitable sector. ${ }^{5}$ How free should the fiduciaries ${ }^{6}$ of charitable hospitals be to transfer their capital assets to for-profit providers and to redirect the value of those assets into areas of need less adequately met by the market? Conversely, how trammeled should contemporary fiduciaries be by the will, expressed or implied, of founders and donors long dead? Parallel questions arise throughout the charitable sector. To quote the title of one recent article, "When Is It Okay to Sell the Monet?"7 What H.G. Wells said a century ago about any modern Utopia seems true today of any dynamic polity: "A periodic revision of endowments is a necessary feature." 8

Over a decade ago, I examined the theoretical side of the question of dead hand control of charitable assets. On the premise that charities should enjoy the maximum imaginable autonomy from both government and donors, I built a case for radical reform: virtually complete elimination of legally enforceable dead hand control, in favor of almost full fiduciary discretion within the broadest possible

conversations, the amounts of money at stake, and the implications of the debate for other nonprofit institutions.").

5 As one of the leading authorities on hospital conversions has observed, "the category of [tax] exempt organizations susceptible to conversion is much broader [than hospitals]. It includes virtually any exempt organization that provides products or services for which there is a significant market-nonprofit book publishers as well as HMOs, and tax-exempt biotechnology research institutes ...." Silk, supra note 3, at 745 .

6 By a convention that I myself have sometimes followed, these agents are often referred to as "trustees." Rob Atkinson, Unsettled Standing: Who (Else) Should Enforce the Duties of Charitable Fiduciaries?, 23 J. CORP. L. 655, 663 (1998). By using the more inclusive term "fiduciary," I mean to expand my coverage in two directions, the horizontal and the vertical. Horizontally, nonprofit organizations come in two basic forms, charitable trusts and nonprofit corporations; both the trustees of the former and the directors of the latter are fiduciaries. Vertically, within charitable organizations, fiduciaries at this first level, the trustees and the directors, typically govern the activities of fiduciaries at a second, structurally lower, level: the charities' managers.

Although the more inclusive term "fiduciary" works nicely for most of my analysis, it will be necessary at times to distinguish trustees from directors. See, e.g., infra Part II.B.2.a (2). At other times, to distinguish between charitable fiduciaries and non-charitable fiduciaries like guardians, trustees of private trusts, and for-profit directors and managers. See, e.g., infra Part II.B.1.b. Finally, some have noted systemic conflicts between charitable fiduciaries at the trustee and director level, on the one hand, and charitable fiduciaries at the managerial level, on the other. See Peggy Sasso, Searching for Trust in the Not-for-Profit Boardroom: Looking Beyond the Duty of Obedience to Ensure Accountability, 50 UCLA L. REV. 1485, 1487-88 (2003) (distinguishes functions of and identifies systemic conflicts between, charities' typically lay "boards" and their typically professional "management"). These latter conflicts, though both theoretically and practically significant, generally lie beyond the scope of this paper.

7 Jennifer L. White, Note, When It's OK To Sell the Monet: A Trustee-Fiduciary-Duty Framework for Analyzing the Deaccessioning of Art To Meet Museum Operating Expenses, 94 MiCH. L. REV. 1041 (1996) (discussing the legal and ethical duties of museum directors in sales of museum assets).

8 H.G. Wells, A MOdern Utopia 94 (1967) (1905 ed.). 
parameters of charity. ${ }^{9}$ Under this proposal, to take the example of hospitals, fiduciaries would be fully entitled to sell their capital assets to a for-profit firm and to devote the proceeds of that sale to whatever alternative charitable purpose they think most conducive to the public good.

To achieve that radical end, legal abolition of dead hand control, I recommended what now seem ironically orthodox means: wholesale, top-down reversal of existing law by either of the two standard routes. On the one hand, state legislatures could simply enact my proposal, overruling the antiquated common law of dead hand control with a forward-looking, charity-liberating statute. ${ }^{10}$ On the other hand, the state supreme courts could accomplish the same end, exercising their inherent power to revise, even reverse, their own precedents. ${ }^{11}$

Either of these alternatives, the legislative or the judicial, could have been less sweeping than I suggested, eliminating some elements of dead hand control, leaving others intact. Unfortunately-at least from my reformist perspective-very little along the lines I recommended has, in the intervening decade, actually happened. ${ }^{12}$ Even as the need to free up charitable assets has increased dramatically, reform has moved glacially; in some places, indeed, dead hand control seems to have frozen still more solidly in place. ${ }^{13}$ An academic paper, of course, cannot fairly be faulted merely because its recommended reforms have not been adopted. But such a paper can certainly be faulted both for not anticipating the failure of orthodox approaches to reform and for not offering an alternative route.

Against that rather bleak background, I offer this second paper on reforming the law of dead hand control. On the theoretical side, it presents a counterpoint to my earlier piece. As the logical compliment to my unorthodox theoretical conclusion there that dead hand control should be entirely eliminated, here I offer an equally unorthodox but thoroughly practical set of means for advancing that end, one case at a time. On the practical side, this paper offers an immediately available set of strategies for removing dead hand control, strategies that can be deployed, in particular cases, right now. The net effect of this piecemeal, practical approach should be to move us, albeit in small,

9 Atkinson, Reforming Cy Pres Reform, supra note 2.

10 Id. at 1154-55.

11 Id. at 1156.

12 For an indispensable survey of these developments, see MARION FREMONT-SMITH, GOVERNING NONPROFIT ORGANIZATIONS 173-86 (2004).

${ }^{13}$ See Horowitz \& Fremont-Smith, supra note 3, at 227 ("Since the mid-1990s, however, more than half the states have enacted conversion statutes codifying the common law rules [of cy pres] to ensure that they can be easily enforced."). 
incremental steps, around the impasse of the dead hand doctrine toward the theoretically higher ground of freer, more fungible charitable assets and increased charitable autonomy.

Part I sketches out the different roads to legal reform, the high road and the low road, with particular reference to removing dead hand control. It suggests, as a descriptive matter, why the usual routes to reform, my high roads of general legislation or sweeping judicial reversals of precedents, are unlikely ways of reducing dead hand control of charitable assets. It then argues, as a normative matter, that this situation justifies less orthodox means. Basically, it comes to this: if the door is jammed, and the house is on fire, it's okay to go out the window. Part II deals with the doctrine of dead hand control in detail, using an extended example: "The Passing of Aunt Estelle and the Advent of Wal-Mart." In the context of that hypothetical case, this part discusses the current legal forms of dead hand control and the orthodox means of their removal. It begins by placing the dead hand of charitable assets in a larger context, comparing dead hand control of charitable assets with dead hand control of assets outside the charitable sector. Within each sector, charitable and non-charitable, it traces parallel orthodox methods for removing dead hand control. In the charitable sector, it shows how these orthodox methods, particularly petitions for judicial reform under the common law doctrines of deviation and cy pres, all too often end in courts' sustaining, rather than relaxing, dead hand control.

Part III searches for an alternative route around this impasse, a route that is at once both practical and unorthodox. The key to mapping out this doctrinal detour is to notice an odd asymmetry in the legal landscape. One the one hand, dead hand control, as a matter of substance, is quite deeply entrenched; on the other hand, as a matter of process, the means for its enforcement are remarkably narrow. Although the courts, consistent with current substantive law, must enforce dead hand control, only a relatively small class of potential litigants is empowered to seek judicial enforcement of that control.

The unorthodox path to reform lies along the contour of this asymmetry. The first secure $\operatorname{step}^{14}$ along this path is for conscientious charitable trustees and their lawyers to collaborate with enlightened state attorneys general. State attorneys general invariably have the power to enforce dead hand control, but they could legitimately forego its exercise if convinced that the departure from dead hand

14 There is, as we shall see, an analytically prior step, charitable fiduciaries' unilaterally disregarding dead hand restrictions. This prospect, however, proves more of a faux pas than a viable first step, for reasons we explore below. See infra Part III.A.1. 
control were in the public interest. By contrast, private parties empowered to enforce dead hand control in their individual capacities have neither the legal obligation nor the economic incentive to seek the greater public good. That problem, however, presents an opportunity, the second step on the path around dead hand control: making a deal with the devil. Private parties with the power to enforce dead hand control, like litigants in other private law suits, can sometimes be induced to settle their legal claims-for the right price, of course.

Here, however, there is a final hurdle: what if, as the theory of bilateral monopoly predicts, these private parties hold out for extortionate prices? To get past this last problem, charitable trustees may need to consider a third step, admittedly a bit of a leap: an alliance with local authorities that have the power of eminent domain. Through the creative use of that power, recently expanded by the United States Supreme Court, ${ }^{15}$ charities may, at least in some cases, be able to force private parties to surrender dead hand control on economically reasonable terms.

By taking these three steps-collaboration with state attorneys general, settlement with private parties, and alliance with governments exercising eminent domain-charitable fiduciaries and their lawyers may be able to avoid dead hand control in many cases, even as that control remains, as a matter of legal doctrine, undiminished. If that is so, then theoretical reformers, with the help of principled practitioners, will not have removed the megalith of dead hand control. But we will have found a way around it. That way is admittedly a detour, not the shortest route from where we are to where we want to be. And that detour will not be open at all times, in every case. But it is a good bit better than what we have now, and a great deal better than nothing.

There may, indeed, be a paradoxical appeal in the limited scope of my present proposal. I have argued before for the abolition of dead hand control of charitable assets, but that is admittedly a radical position. Most of my fellow reformers, in practice and in academia, prefer a more moderate advance beyond existing law. This latter paper, then, should be more to their liking. The more radical among us, for our part, can both welcome these fellow travelers to our broader cause and enjoy the company of none other than Jefferson, who preached our straighter if narrower way: "This corporeal globe,

15 Kelo v. City of New London, Conn., 545 U.S. 469 (2005). 
and everything upon it, belong to its present inhabitants during their generation."

\section{MAPPING THE ROADS TO REFORM OF DEAD HAND CONTROL}

Before we turn to problem of dead hand control, we must say a bit more about how we plan to approach it. In particular, I need to account for why I am not recommending a more traditional approach and, beyond that, why that traditional approach has not already been taken.

\section{A. The Separation of High Academic Theory from Principled Routine Practice}

The metaphor of my title comes ultimately, of course, from a Scottish folk song. More immediately, if less obviously, it alludes to the keynote address at the first annual Philanthropy and the Law Conference held at NYU in 1989. In that address Prof. John Simon of the Yale Law School and the Yale Program on Nonprofit Organizations mapped out the two principal routes of nonprofit scholarship: the High Road of grand theory and the Low Road of empirical research. By grand theory, Prof. Simon meant scholarship that draws primarily on political theory, moral philosophy, literary criticism, and economic analysis in its model-building mode; by empirical research, he had in mind history and the social scientific methods of sociology, anthropology, political science, and economics in its model-testing mode.

Prof. Simon's two-road map to nonprofit scholarship made a descriptive, not a normative, point. By designating grand theory as the High Road and empirical research as the Low, he did not mean to imply that the former was in any sense better than the latter. $\mathrm{He}$ simply meant that the empirical was, as we say, "closer to the ground." If anything, the metaphor bespeaks sympathy, not scorn, for the empiricists' route. Empiricists, Prof. Simon genially suggests, set

${ }^{16}$ Letter from Thomas Jefferson to Samuel Kercheval (1816) in THE WRITINGS OF Thomas JefFerson AT 15:43 (Lipscomb \& Burgh eds., Mem. Ed. 1904). Even as I am not the first to notice the parallel between dead hand control in philanthropy and constitutional law, see supra note 2, so I am not the first to invoke the name of Jefferson against dead hand control, see Lewis M. Simes, Public Policy AND tHe Dead Hand 59 (1955) (citing Jefferson's observation that "the earth belongs always to the living generation" in support of the Rule Against Perpetuities limit on dead hand control); Lewis M. Simes, The Policy Against Perpetuities, 103 U. PA. L. REV. 707, 723 (1955) (same). Nor is Jefferson the only Enlightenment icon to speak against the dead hand. In attacking the Scottish law of entails, Adam Smith decried its foundation, "the most absurd of all suppositions, the supposition that every successive generation have not an equal right to the earth." See A.W.B. SIMPSON, LEGAL THEORY AND LEGAL HISTORY: ESSA YS ON THE COMMON LAW 157 (1987) (quoting Smith). 
their feet firmly and fittingly on the ground; theorists lift their heads aloofly, not just loftily, into the clouds.

If there was any stronger element of censure implicit in Prof. Simon's speech, it was purely by way of omission. He made, as I recall, no more than passing mention of a third kind of scholarship, traditional doctrinal analysis. In that omission, he was very much reflecting the perspective of elite academic lawyers, now as well as then. In intellectually ambitious schools of law, discussion of the law as it actually is, without light from outside disciplines, has been in rather serious disfavor for at least a full academic generation, if not for the better part of a century. In terms of Prof. Simon's metaphor, mapping out legal doctrine is never more than a preliminary move toward a more serious matter. It is only a running start, background for analysis along the high or low road, part of the raw data to be processed by other, typically extra-disciplinary, methods. Doctrinal analysis in a purely expository sense, as a guide to lawyers serving clients-public, private, or nonprofit-has come to be seen as distinctly low-brow, if not disreputable.

This shifting of legal doctrine from center stage has not been an entirely welcomed development, either inside or outside academia. ${ }^{17}$ In the academic context, which is really something of a crossfire, one must locate one's use of legal doctrine with care. In my prior article on dead hand control, I used legal doctrine very much in the academically acceptable way; in this article, I do not mean to switch sides. Instead, I mean to use doctrine in a third way, different but certainly not entirely novel. I propose to use legal doctrine neither as the raw material for scholarly analysis, nor as a guide to routine professional practice by the bar and the bench, but as a means to achieve the ends suggested by scholarly analysis. In terms of my titular metaphor, borrowed from my mentor Prof. Simon, I do not want merely to place doctrinal analysis at the beginning of the scholarly road, as a kind of running start to theoretical or empirical analysis. Nor do I want to treat doctrinal analysis as an end in itself, or even something close, as a way of informing practicing lawyers and judges. Rather, I want to use doctrinal analysis as a means of getting around an impasse in the more routine road to legal reform. In that sense, I want to use what I will call "principled practice" to take us, guided by the recommendations of grand theory, to their realization.

17 Judge Harry T. Edwards of the D. C. Circuit has been a particularly vocal critic of these scholarly trends. See Harry T. Edwards, The Growing Disjunction Between Legal Education and the Legal Profession, 91 MICH. L. REV. 34 (1992). 


\section{B. Impasses on the High Road to Reform: The Failure of Traditional Legislative and Judicial Approaches}

Legal theory, along both High and the Low roads, has often been the guide of legal reform, in the field of charity as elsewhere. It is important, therefore, to see how what I propose here is different. In their more traditional mode, reformist scholars scrutinize legal doctrine or practice through their chosen analytic lens, then recommend that the legal landscape be reshaped to conform to their normative blueprints. Typically, perhaps a bit smugly, we academics leave matters there; at most, we suggest that either legislatures or appellate courts do the recommended reshaping by writing our recommendations into law.

Think of this as the High Road to legal reform. This is reform at the wholesale, rather than retail, level; it aims at direct change in the law on the books, either the codified law of legislation or the common law of judicial precedents. Such reform may, of course, be incremental, rather than radical: small amendments to this code provision or that, rather than sweeping re-codifications; gradual erosion or extension of an existing line of cases, as opposed to reversals of long-standing doctrines and precedents. But, be its progress evolutionary or cataclysmic, this kind of reform is always explicit; if not "on the books" then at least discoverable in the books. This is very much the path to reform that I recommended in my early piece on dead hand control.

The path I recommend here seeks the same end, but by a different means: the Low Road of my title. Before setting out that path, we must answer a logically anterior set of questions: why have traditional reformist measures not worked well here? Could it be the case that loosening dead hand control has failed because it is a bad idea? Perhaps. But the reasons for the disappointing progress of dead hand reform may have little to do with weaknesses in the substantive case for reform, and much to do with structural problems in achieving reform on this particular point through the traditional means of legislation or high-profile, precedent-setting adjudication.

On the legislative side, dead hand control presents classic problems: lack of salience and attendant collective action paradoxes. ${ }^{18}$

18 See ManCUR Olson, The Logic of COLlective ACtion $125-29$ (1971). The basic problem, in Olson's terms, is this: "Since relatively small groups will frequently be able voluntarily to organize and act in support of their common interests, and since large groups normally will not be able to do so, the outcome of the political struggle among the various groups in society will not be symmetrical." Id. at 127; see also Jesse Dukeminier \& James E. Krier, The Rise of the Perpetual Trust, 50 UCLA L. REV. 1303, 1317 (2003) [hereinafter, Perpetual Trust] (suggesting that collective action problems may have forestalled statutory 
Cases of dead hand control come up fairly often, ${ }^{19}$ sometimes quite sensationally. ${ }^{20}$ But, though they may attract considerable public attention, their redress is not likely to attract significant public support. Compared to more basic, bread-and-butter issues, dead hand control is predictably placed, again and again, on the back burner-if not on the bottom shelf. ${ }^{21}$

In the courts, one might think that circumstances would, by contrast, be more favorable to reform. After all, as we shall see, charitable fiduciaries can freely petition courts, under current doctrine, to loosen both administrative and substantive restrictions on their organizations' assets. ${ }^{22}$ The benefits of this loosening would redound, at least in large measure, to their own organizations. This would not be the case, however, with suits that seek, not the relaxing of particular restrictions, but general removal or relaxation of dead hand control. Indeed, asking for the latter when the former would suffice may incur the risk of overreaching. Seeking the whole loaf to share with all charities, in other words, may diminish any particular charity's chance of getting a half-loaf of its own.

And what charities may thus be disinclined to seek, courts, for their part, may be disinclined to grant. Courts may be doubly indisposed toward radical, as opposed to incremental, change here. Sweeping reversal of the existing doctrine of dead hand control may be unappealing to judges of both the "activist" and the "strict constructionist" stripe. In general, all judges are under increased scrutiny for "making," as opposed to applying, law. In particular, the elimination of the usual approach to dead hand control would reduce the range of judicial power by removing court's authority, under the

alteration of the Rule Against Perpetuities until the advent of the generation-skipping transfer tax gave the Rule great salience to wealthy and powerful constituencies); $c f$. Anthony Downs, Up and Down with Ecology: The "Issue-Attention Cycle", in ANTHONY DownS, POLITICAL THEORY AND PUBLIC CHOICE 100-12 (1998) (describing, with particular reference to environmental issues, "a systemic 'issue attention cycle' [that] seems strongly to influence public attitudes and behavior concerning most key domestic problems.").

${ }^{19}$ See, e.g., Robertson v. Princeton University, No. C-99-02 (N.J. Super. Ct. Ch. Div. 2007); In re Milton Hersey School, $590 \mathrm{~Pa} .35$ (2006).

${ }_{20}$ See, e.g., Robert K. Durkee, Letter to the Editor, Princeton Has Done the Right Thing, WaLl St. J., Oct. 18, 2007, at A15; John Hecinger, Princeton Reimburses Donors' Foundation, WaLl ST. J., Mar. 13, 2007, at A2; Jessica Bruder, Give Us Back the Money, Heirs Tell Princeton, N.Y. TIMES, Jun. 20, 2004, at 3; Robert Frank and Sarah Ellison, Meltdown in Chocolatetown-Controlling Trust at Hershey Bows to Opposition to Sale; Company Faces Future Alone, WALl ST. J., Sept. 19, 2002, at B1; Nelson D. Schwartz, Hershey Overhauls Its Board of Directors, N.Y. TIMES, Nov. 12, 2007, at 12.

21 What is worse, as we shall see, where it has become salient, it has tended to be resolved against the interest of charitable fiduciaries, not an especially politically powerful group. Infra Part III.B.3.

${ }^{22}$ See infra Part II.B.2.c. 
doctrines of cy pres and equitable deviation, to say when the terms of charitable gifts can be altered. Incremental change, through modest expansion of these orthodox judicial powers, gives courts more control than does my more radical, abolitionist alternative. Thus conservative courts are likely to give no relief, lest they transgress their commitment to apply, not make, the law. Activist courts, on the other hand, may well be disinclined to change law in a way that reduces the very scope of their activism. Incremental reform, then, may be an over-determined, not just a predictable, outcome.

\section{Opening a Low Road to Reform: Toward Collaboration Between High Academic Theory and Principled Routine Practice}

If the analysis in the last section is correct, we should not be surprised that neither legislatures nor courts have embraced sweeping liberalization in the law of dead hand control. Nor should we expect any such change from either of these quarters any time soon. This need not, however, be taken as a counsel of despair; it can, instead, be taken as a call to action, albeit along less traditional lines. Thus, in the face of an impasse on the high road to reform, I offer my alternative approach: the low road of principled, reformist practice in alliance with high academic theory.

The principled practitioners I have in mind will mostly be legal counsel for charitable organizations and charitable fiduciaries themselves. What I want to map out is a way for these agents of charity to effect, not only the particular changes they think appropriate for their own organizations, but also an incremental reduction of dead hand control in general. The next step in that process is to turn to the present law of dead hand control and map out both its scope and its limitations. The next section, accordingly, identifies both the roadblocks that the dead hand throws up against movement of charitable assets and the ways that orthodox doctrine allows around those impediments.

\section{THE DOCTRINE OF DEAD HAND CONTROL AND ITS ORTHODOX EXCEPTIONS}

It is important, for purposes of our analysis, to see that the dead hand control of social assets is not a phenomenon limited to the nonprofit sector. Comparing dead hand control in the private and charitable sectors sheds significant light on the latter. In both sectors, dead hand control takes various forms; some forms, we shall see, are relatively easy to engineer around, some dramatically less so. The more problematic forms appear in the charitable sector; the reasons 
for their being more problematic are best seen against the background of their private-sector counterparts.

\section{A. The Hypothetical Case: The Saga of Aunt Essie's Farm and Fortune}

To put some flesh on what would otherwise be a very dry skeleton indeed, I will illustrate the various forms of dead hand control with an extended hypothetical scenario. To cover all the necessary ground, in both the private and the charitable sectors, that scenario will have to be complex, if not Faulknerian. Having been forewarned, consider the saga of Aunt Essie's Farm and Fortune.

\section{Aunt Essie's Place}

Estelle MacCabee ${ }^{23}$ was the fourth child and only daughter of a prosperous tobacco and cotton farming couple in the rural community of Indiantown, in the South Carolina Low Country. Her parents died in the flu epidemic of 1918, when she was only eighteen. They left each of their four children equal shares of their 640 acre farm; Aunt Essie's quarter, 160 acres of prime farmland, includes two dwellings. ${ }^{24}$ The first is her parents' house, which they built in the last decade of the nineteenth century; the second is the "Old Manse," the original eighteenth century minister's residence associated with the neighboring Indiantown Presbyterian Church. Aunt Essie herself never married, and, with the exception of two years at a female seminary and finishing school in Columbia, she lived her whole life on the farm her parents left her. For sixty years she managed the place herself, with the help of various share-croppers, day laborers, and relatives.

In her later years, she relied primarily on her two nephews, Sutherland and Northrop, sons and namesakes of her older two brothers. Although she directed the cultivation of the East Forty essentially herself until her death, she found she could live more and more comfortably on her passive investments. In 1975, she started renting the North and South Forties to Northrop and Sutherland, respectively, and she sold the West Forty to her youngest brother, Wesley. Savvy lady that she was, Aunt Essie had her lawyer insert a very specific clause in the deed: "provided, however, that the

23 The Carolina MacCabees are, perhaps, a more cadet but no less philanthropic branch of the family chronicled in John Simon, Charity and Dynasty Under the Federal Tax System, 5 PROB. LAW. 1, 3-6 (1978) ("the life story and also the after-life story of a fictional citizen named Henry MacCabee, who grew rich in real estate and race horses").

${ }^{24}$ A plat of Aunt Essie's farmland is included as an appendix to this paper. 
aforesaid West Forty shall never be used for anything other than traditional agricultural purposes."

Aunt Essie used part of the proceeds of the sale of the West Forty to transform the East Forty into something of a country estate. She converted the much-neglected "old Manse" into a comfortable guest house for visiting nieces and nephews. Carefully leaving the richer tobacco lands undisturbed, she dug a fish pond and stocked it with bream and bass, built a stable for her horses, and enclosed the less productive of her fields as a pasture.

With considerable trepidation, she invested the rest of the proceeds from the sale of the West Forty in the stock market. Thinking it at least poetically appropriate that tobacco land should be converted into tobacco company stock, she bought big in R. J. Reynolds. Their leveraged buy-out, dubious though it may have been in other respects, ${ }^{25}$ made Aunt Essie a much more comfortable woman. From that, as from all her earnings, she dutifully tithed her Biblical ten percent.

Aunt Essie, like Melville's Ishmael, "was a good Christian, born and bred in the bosom of the infallible Presbyterian Church, ${ }^{, 26}$ in her case, the congregation at Indiantown. Its eighteenth century meetinghouse stands just up the road from the East Forty of Aunt Essie's farm. In her 92 years of membership, she never missed more than one Sunday worship service in a thousand; until well into her nineties, she walked rather than drove to Church. Her self-assigned seat was directly beneath the Tiffany glass window donated by Bernard M. Baruch in loving memory of the people of Indiantown. Mr. Baruch had owned a quail-hunting plantation across Mingo Creek, and Aunt Essie's brothers had been his favorite and most faithful guides. Aunt Essie herself had donated the Dutch-import pipe organ (a baroque mahogany and brass monstrosity some find out of keeping with the Church's austere meetinghouse style).

\section{Aunt Essie's Passing}

Aunt Essie died at the age of 100 in the year 2000, survived by her youngest brother Wesley and her nephews, Northrop and Sutherland, and their children. Her estate consisted of her remaining 120 acres of ancestral farmland, cash and securities worth about $\$ 1,000,000$, assorted personal effects, and an important, if forgotten, incorporeal

2s See Claudia H. Deutsch, RJR's Brave New World, N.Y. TIMES, Sept. 17, 1989, § 3, at 31 (describing the results of a junk bond-financed leveraged buy out by which RJR Nabisco, Inc., "went private").

26 HeRMANN MELVILle, MOBy DICK 57 (Easton Press 1977) (1951). 
hereditament. Aunt Essie disposed of all of this property by will. Stripped of boiler plate and paraphrased into non-technical terms, here are her will's essential provisions:

\section{Specific Devises:}

(1) The North Forty to Northrop, for life; at his death, the remainder to his children.

(2) The South Forty to Northrop in trust, to hold for the benefit of Sutherland for life and, at Sutherland's death, for the benefit of his children.

(3) The East Forty to the Church, her house to be used as a retirement home for its past pastors and their families and the pond and pasture to be kept as a park for members of the congregation.

Specific bequests: $\$ 500,000$ to the Indiantown Presbyterian Church Child Care Program.

Residuary clause: Everything else in equal and undivided shares to Northrop and Sutherland.

\section{The Advent of Wal-Mart}

As fate or higher forces would have it, in the very year that Aunt Essie passed away, leaving her land to others, Wal-Mart appeared, wanting land of its own in the very same place. Although Indiantown itself is an unincorporated rural community with a small and dispersed population, it enjoys a strategic location that makes it the ideal site for a Supercenter. As you can see from the plat of Aunt Essie's farm, Indiantown lies almost precisely in the center of four small but thriving tobacco market towns: Kingstree to the northwest, Lake City to the northeast, Hemingway to the southeast, and Andrews to the southwest. Each of these towns is closer to Indiantown than to any other or to any of the cities in the region.

On the same day that Aunt Essie's will is probated in the county seat, Kingstree, Wal-Mart scouts arrive to seek the forty acres they 
need for their regional emporium. As they see it, all relevant roads literally lead to Aunt Essie's farm.

\section{B. The Dual Domain of the Dead Hand: Private and Charitable Assets}

The imposition of dead hand control is quite common in the private, for-profit sector. Some of these forms occur mostly in commercial transactions; others, mostly in intra-family, gratuitous transfers. In the saga of Aunt Essie's farm, we can see instances of both. What is more, both will shed important light on parallel forms of dead hand control in the charitable sector. ${ }^{27}$

\section{Dead Hand Control Outside the Charitable Sector}

Before the advent of Wal-Mart, three quarters of Aunt Essie's farm passed, under her will, into private hands. Wal-Mart is eager to purchase any of them, and the current holder of each is eager to sell. Each parcel, however, is subject to a different set of what appear to be dead hand impediments to doing the deal. We need now to consider each of these in turn. Following Wal-Mart's lead, let us focus first on the West Forty; to further our plot, let's say that it lies, ever so slightly, farther in the direction of the larger two of the four neighboring towns.

\section{a. The West Forty: Re-Bundling Rights Commercially Transferred}

Back in 1975, you will remember, Aunt Essie sold the West Forty to her brother Wesley; now Uncle Wesley wants to sell the West Forty to Wal-Mart for its Supercenter. On the face of his deed, this would seem to be impossible; he took the farm, you will recall, subject to the condition that it never be used for anything other than traditional agricultural purposes. Digging a little deeper into the state of title as to the West Forty, however, reveals that the Wal-Mart deal is definitely doable - though not on terms nearly as favorable to Uncle Wesley as we can safely assume he would like.

To see why this is so, we have only to ask ourselves this: what would happen if, in violation of the prohibition in his deed, Uncle Wesley sold the land to Wal-Mart, and Wal-Mart proceeded to build a

27 The non-governmental economic world does not divide without remainder, as I suggest in the text, into the private, for-profit sector and the charitable sector. The charitable component is itself part of a larger nonprofit sector, which includes mutual benefit organizations and cooperatives. For purposes of the present analysis, however, these non-charitable components of the nonprofit sector need not concern us, and we can more conveniently, if less precisely, contrast the charitable sector with the for-profit sector. 
Supercenter? In the contemplation of the law, the interest Aunt Essie transferred to Uncle Wesley would simply cease to exist; in the language of the law, his successor in that interest, Wal-Mart, would be defeased. ${ }^{28}$

What, then, would become of the West Forty? It would not, of course, cease to exist. Nor could it return in legal title to Aunt Essie, who is dead. Instead, title would pass to her successors in interest: her heirs, if she had left no will; those designated in her will, since she did. Her will, however, makes no mention of this possibility. Not to worry. The right to receive the West Forty will have passed, sub silencio, under the residuary clause of her will; as we have seen, its boilerplate language left the "rest, residue, and remainder" of her estate to her nephews, Northrop and Sutherland.

In searching the title to the West Forty, Wal-Mart's lawyers will certainly have discovered this "cloud." Until this cloud is removed, Wal-Mart is never going to buy Uncle Wesley's interest, only to have that interest disappear-technically speaking, defease-in favor of Northrop and Sutherland. This could consign Uncle Wesley and his successors in interest, whether by sale or gratuitous transfer, to being West Forty farmers forever.

But there is, most significantly, another alternative: Wal-Mart can simply buy the interest of Northrop and Sutherland along with that of Uncle Wesley. In a fairly straight-forward transaction-albeit quadrilateral rather than bilateral-Wal-Mart can buy full legal interest in the West Forty. Technically speaking, Wal-Mart would buy a fee simple determinable from Uncle Wesley and a possibility of reverter from Northrop and Sutherland, jointly. If that deal goes down, the apparently permanent dead hand control of Aunt Essie will end, then and there. Unlike poor Humptey-Dumptey, Aunt Essie's full fee simple absolute in the West Forty, first broken apart by her sale of a lesser, defeasible fee to Uncle Wesley, then further fractured by the passing of her reversionary interest to Northrop and Sutherland by her will, can be fairly readily re-assembled.

But, you might ask, would that not be, somehow, wrong? More specifically, would it not frustrate Aunt Essie's wishes, her intent with respect to land that was hers to sell or give away as she saw fit?

28 The example in the text uses a defeasing condition, primarily because the effects of its violation are more dramatic than those of alternative means of imposing very similar restrictions. See Adam J. Hirsch \& William K. S. Wang, A Qualitative Theory of the Dead Hand, 68 IND. L.J. 1, 18 (1992) (noting parallel functions of real covenants and defeasing conditions). These latter include the full available range of negative servitudes: easements, real covenants, and equitable servitudes. Negative servitudes are typically enforced by damages or injunctions, much less drastic relief than defeasance. JESSE DUKEMINIER \& JAMES E. KRIER, PROPERTY 892-93 (5th ed. 2002). 
In the first place, as we shall see more clearly in a moment, Aunt Essie's power to control the destiny of her land is by no means absolute. In the second place, and more significantly here, the sale to Wal-Mart may very well have accomplished exactly what she had in mind.

That might have been either of two closely related things. On the one hand, Aunt Essie may have wanted to insulate herself and her successors in interest, as holders of the other three quarters of the farm, from what economists call negative externalities. ${ }^{29}$ Savvy as she was, Aunt Essie may have foreseen a very real risk in selling her entire interest in the West Forty to Uncle Wesley. That risk, in a word, is trailers. Not the bucolic hay-wains that grace Constable landscapes, but the unsightly mobile homes that, to her mind, mar much of the rural south, and elsewhere. Like many other real estate developers, to protect the lands she retained from undesirable activities on the land she transferred, Aunt Essie may have imposed restrictions on what she transferred in favor of what she retained. ${ }^{30}$

On the other hand, Aunt Essie may not have been concerned about the downside risk of trailers, but about the upside gain from any form of real estate development beyond the traditionally agricultural. She may, in other words, have anticipated exactly the situation that has arisen, the advent of a Wal-Mart Supercenter. She may have wanted, not to prevent Wal-Mart from coming to the West Forty, but to preserve to herself and her nephews some significant part of the premium that Wal-Mart would be willing to pay for the land above its value for agricultural purposes.

If either of these, the downside risk or the upside return, was Aunt Essie's concern, then it is almost bound to be covered in the four-way Wal-Mart deal I have described. If Northrop and Sutherland prefer Wal-Mart's price to the continued use of the West Forty as a farm, they can sell their effective veto of all non-agricultural uses. If, on the other hand, Wal-Mart does not meet their price, then they can simply hold on to their joint veto power. Her will, were it to prevent negative externalities or to preserve development opportunities, will have been done, after her death as well as during her life.

But Aunt Essie may have had something entirely different in mind; she may have wanted to keep the West Forty in agricultural use, even over the desire of Northrop and Sutherland to sell it to Wal-Mart. We

29 Richard A. POSNER, ECONOMIC ANALySIS OF LAW 81 (2003 ed.) (1973); MARK SEIDENFELD, MICROECONOMIC PREDICATES TO LAW \& ECONOMICS 63 (1996).

30 See DUKEMINIER \& KRIER, PROPERTY, supra note 28 at 859 (noting how "bargains between neighboring property owners can operate to allocate resources efficiently by arranging land uses so as to minimize conflicts"). 
will see just such a wish in her disposition of two of the other quadrants of her farm, the South Forty and the East Forty. There, her dead hand preferences will prove much more difficult to remove. Before turning to that, however, we need to examine another example of how readily removable another apparent instance of dead hand control can be.

\section{b. The North Forty: Re-Bundling Successive Interests Held in a Nonfiduciary Capacity ${ }^{31}$}

Northrop, as Aunt Essie well knew, is nobody's country bumpkin. As we have just seen, he realizes that he may be able to share the gain from the Wal-Mart deal with Uncle Wesley and Cousin Sutherland. But he has bigger plans: he wants to secure all the gain for himself and his immediate family. Rather than join with Sutherland in selling their joint veto over the development of the West Forty to Wal-Mart, he plans to exercise that veto unilaterally, thus effectively foreclosing the deal. That done, he will then offer to sell Wal-Mart his own family's interests in the North Forty.

There is a snag here, but it is readily removable. Aunt Essie, remember, did not leave the North Forty to Northrop alone. In legal terms, she left him a life estate, with the remainder to his children. Under traditional common law rules, Northrop, acting alone, could not convey full, fee simple absolute title to Wal-Mart. He could only transfer what he Aunt Essie left him, his life estate. Wal-Mart most likely will not want that, bounded, as it is, by the relatively short and radically uncertain span of a single human life. ${ }^{32}$

Fortunately for Northrop, that is hardly the end of the matter. If Northrop can get the remainder folk to join in the deal, he and they can convey the fullest legally cognizable interest in the North Forty to Wal-Mart, or, for that matter, to anyone they want. ${ }^{33}$ Somewhat surprisingly, perhaps, Northrop can engineer this deal despite the fact that, in the eyes of the law, the remainder folk who must agree to it include children he has not yet fathered, and who may never even be conceived. He could perhaps approve the deal on their behalf as their parent and legal guardian ${ }^{34}$; alternatively, and somewhat less

31 See RESTATEMENT (THIRD) OF TRUSTS $\S 5 \mathrm{cmt}$. b (discussing trusts and successive legal estates).

32 See, e.g., C. Dent Bostick, Loosening the Grip of the Dead Hand: Shall We Abolish Legal Future Interests in Land?, 32 VAND. L. REV. 1061, 1062 (1979) ("Unfortunately, few purchasers are willing to invest in life estates pur autre vie or interests subject to partial or total divestment.").

33 Id.

${ }^{34}$ See Gail Boreman Bird, Trust Termination: Unborn, Living, and Dead Hands-Too 
conveniently, he could have a guardian ad litem or conservator appointed to consider whether the transaction is favorable to their interest $^{35}$; at very worst, he would have to petition a court, under its powers of equity, to order the sale for the benefit of all interested parties, including all holders of present and future interests. ${ }^{36}$

Whatever technical method Northrop used to act on behalf of his children, the propriety of the transaction would turn on whether the present value of their remainder interest is increased by making the sale. It is not hard to imagine that that is the case in the proposed shift from agricultural to retail use. What is more, there is every reason to think that the interest of Northrop and the remainder-folk are aligned. $\mathrm{He}$ is, after all, their parent; beyond that, any increase in the value of his life estate in this case is almost certain to increase the value of their remainder.

As a practical matter, the proceeds of the sale could be divided among Northrop and the remainder-folk in either of two basic ways. If they could agree on his life expectancy, they could divide the sales proceeds outright, at the time of sale. Even if they cannot, they can simply place the proceeds in a trust, with the income to go to Northrop for life, and the remainder, at his death, to his children. ${ }^{37}$ This, of course, is essentially the same arrangement that Aunt Essie made in her will, with this crucial difference: by their joint action, quite independently of her intentions in the matter, they will have liquidated her land.

But what if Northrop and his children, or their guardian in this matter, cannot agree on either the decision to sell the land or on how to divide the proceeds? The general rule, by either common law or statute, is that any co-owner of a consecutive interest in land can force

Many Fingers in the Trust Pie, 36 HASTINGS L.J. 563, 600 (1985) ("Under the doctrine of virtual representation, the unborn members of a class of beneficiaries may be represented by the living members of the same class or by those having substantially similar interests so as to effectively protect the interests of the unborn.) (emphasis added).

33 Id. at 602-05 (describing extensive, though limited, utility of guardian ad litem mechanism in modifying and terminating trusts with unborn beneficiaries); see also Martin D. Begleiter, The Guardian Ad Litem in Estate Proceedings, 20 WiLlaMETTE L. REV. 643, 669, 746 (1984) (arguing that a conservation, or guardian of the property, is appropriate mechanism for handling a ward's property in non-litigation contexts).

36 LEWIS M. SIMES, LAW OF FUTURE INTERESTS $\S 53$ (2d ed. 1966) ("By the weight of authority, it is held that a court of equity has the power to order a judicial sale of land affected with a future interest and an investment of the proceeds, where this is necessary for the preservation of all interests in the land."); see also LEWIS M. SIMES \& A. SMITH, THE LAW OF FUTURE INTERESTS $§ 1941$ (2d ed. 1956).

37 See SIMES, LAW OF FUTURE INTERESTS, supra note 36 at $\S 53$ (describing this arrangement). 
its sale and the division of the proceeds. ${ }^{38}$ If contested, this alternative, a suit for partition, might be more costly and inconvenient for Northrop. But the result, if he won, would be the same: he could have the land sold to Wal-Mart, with the proceeds divided between himself and his children. Aunt Essie's division of her fee simple absolute in the East Forty into a life estate in Northrop and a remainder in his children, irrespective of her intentions in that division, could almost certainly be undone, one way or another, to permit a sale of a full fee simple absolute to Wal-Mart. Just as her division across space in the prior example can be reversed, so, here, can her division across time. Here, as there, her apparent dead hand control can be removed, more or less easily, by the action of living holders of readily identifiable and transferable interests.

But either of those options would end our saga too soon. Strictly for purposes of examining other, more problematic, forms of dead hand control, we need to add a complicating twist to our plot at this point. Ironically, it has nothing to do with title to the North Forty, and yet it is almost certainly insurmountable. The extraneous, plotadvancing problem is this: I have placed Northrop in the Biblically embarrassing position of serving two masters. Under another dispositive provision of Aunt Essie's will, remember, he holds the South Forty as trustee for his cousin Sutherland and Sutherland's children. In that capacity, Northrop must not only consider their interests as well as his own; he must, in cases of conflict, put their interests first. ${ }^{39}$ If Sutherland's folk can benefit from selling the South Forty to Wal-Mart, then Northrop must do the deal for them with their land, rather than for himself, with his own.

\section{c. The South Forty: Private Property in Trust with the Full Range of Dead Hand Controls}

So far, we have been considering transfers of assets that private individuals hold either in their private, individual capacities or as guardians for other individuals. In those cases dead hand control is, at

38 See, e.g., CONN. GEN. STAT. § 52-500 (2005). The statute, entitled "Sale of Real or Personal Property Owned by Two or More" provides, in pertinent part:

Any court of equitable jurisdiction may, upon the complaint of any person interested, order the sale of any estate, real or personal, owned by two or more persons, when, in the opinion of the court, a sale will better promote the interests of the owners. The provisions of this section shall extend to and include land owned by two or more persons, when the whole or a part of such land is vested in any person for life with remainder to his heirs, general or special, or, on failure of such heirs, to any other person, whether the same, or any part thereof, is held in trust or otherwise.

39 GEORGE T. BOGERT, TRUSTS 341 (6th ed. 1987). 
least in principle, quite easy to overcome. Now we need to examine a more difficult kind of case, where private interests are held in trust. Trusts raise issues of dead hand control not found either where individuals hold property in their individual capacities or even where fiduciaries such as guardians hold property for others.

\section{(1) The Peculiar Character of Private Trusts}

The history of trusts is long and convoluted, and their present permutations may be quite complex, as Aunt Essie's arrangements for the South Forty suggest. But the basic structure is simply and elegantly triangular: one person, the settlor or grantor, transfers legal title to assets to a second person, the legal owner or trustee, to hold and manage for the benefit of a third, the equitable owner or beneficiary. ${ }^{40}$ As generally understood, the trustee operates under two essential fiduciary duties, care and loyalty. ${ }^{41}$ The duty of care requires, as the very term suggests, that trustees must, upon pain of legal penalties, manage the assets committed to them with a legally mandated degree of effort and skill-in a word, care. ${ }^{42}$ Even more basically, the duty of loyalty requires trustees to manage the assets in their care for the good of the beneficiaries, not for their own private, personal gain or for the advantage of third parties. ${ }^{43}$

But all fiduciaries operate under the duties of care and loyalty. Thus, as we have seen, if Northrop is to act as guardian of his children's property, he must not act for his or others' benefit against theirs; even in acting in his children's interest, he must not fall below generally accepted managerial standards. How, then, does Northrop's position as guardian of his minor children differ from his position as trustee of the South Forty for his cousin Sutherland's family? The

40 See John H. Langbein, The Contractarian Basis for the Law of Trusts, 105 YALE L.J. 625,627 (1995) ("The owner, called the settlor, transfers the trust property to an intermediary, the trustee, to hold it for the beneficiaries.").

41 Id. at 655 ("The law of fiduciary administration, the centerpiece of the modem law of trusts, resolves into two great principles, the duties of loyalty and prudence."). As Langbein points out, "subrules of fiduciary administration abound," but "all these rules are subsumed under the duties of loyalty and prudence, they are means of vindicating the beneficial interest." Id. at 656 (citation omitted). See also, PRINCIPLES OF THE LAW OF NONPROFIT ORGANIZATIONS $\$ 300$ (Am. Law. Inst. 2007) [hereinafter, A.L.I. PRINCIPLES] ("Each governing board member shall in good faith exercize the fiduciary duty of loyalty $(\$ 310)$ and care $(\$ 315) . ") ;$ id. cmt (b) ("it is traditional to refer to the twin duties of loyalty and care,").

42 RESTATEMENT (THIRD) OF TRUSTS $\$ 227$ (1992) (discussing the Prudent Investor Rule); Langbein, supra note 40 at 656.

${ }^{43}$ Id. See also Evelyn Brody, The Limits of Charity Fiduciary Law, 57 MD. L. REv. 1400, 1440 (1998) ("Legal disputes involving nonprofit fiduciaries generally deal with breaches of the duty of loyalty rather than the duty of care [because] [s]elf-dealing and other conflicts of interest go to the heart of the fiduciary relationship."). 
difference lies in a third duty, that of obedience, ${ }^{44}$ which makes some fiduciary relationships, including that of trustee, more flexible. To see why this is so, we need to examine Northrop's plan, as trustee for Sutherland's family, to sell the South Forty to Wal-Mart.

Feeling obliged, if not eager, to do for Sutherland and his family what he would happily have done for himself and his own family, Northrop takes a closer look at the provisions for the South Forty in Aunt Essie's will. Here is what he finds:

\section{The South Forty to Northrop in trust, to hold for the benefit of Sutherland for life and, at Sutherland's death, for the benefit of his children.}

Were this the only testamentary provision as to the South Forty, Northrop could dispose of that parcel in essentially the same way he hoped to dispose of the North Forty. He could simply sell the land to Wal-Mart and invest the proceeds for the benefit of Sutherland for his life, then for his children. As a general rule of trust law, trustees are empowered to convert trust assets from one form to another. In the words of the Restatement (Second): "The trustee can properly sell trust property if . . . such sale is necessary or appropriate to carry out

44 The $u r$-source of this concept, so far as I can tell, is DANIEL L. KURTZ, BOARD LIABILITY: GUIDE FOR NONPROFIT DiRECTORS 85 (Moyer Bell Ltd. 1988). See also Peggy Sasso, supra note 6, at 1520 (citing Kurtz for the proposition that "The not-for-profit director is held to three fiduciary duties: the duty of care, the duty of loyalty, and the duty of obedience."); see also Boisture \& Varley, supra note 4, at 230 (referring to "the duty of fidelity to donors" intent"); $c f$. FREMONT-SMITH, GOVERNING NONPROFIT ORGANIZATIONS, supra note 12, at 226 (citing Kurtz on the duty of obedience but concluding that "to the extent that the duty of obedience does not carry with it a duty to assure that the trust is meeting contemporary needs, it does not set forth an appropriate standard."); Brody, supra note 43, at $1406 \mathrm{n} .30,1475$ (noting and adopting tendency to subsume the duty of obedience under the duties of care or loyalty); AMERICAN BAR ASSOCIATION SECTION OF BUSINESS LAW, GuidebOOK FOR DiRECTORS OF NONPROFIT CORPORATIONS 21, (George W. Overton ed., 1993) ("The Duties of Care and Loyalty are the common terms to describe the standards which guide all actions a director takes."); see also Harvey J. Goldschmidt, The Fiduciary Duties of Nonprofit Directors and Officers: Paradoxes, Problems, and Proposed Reforms, 23 J. CORP. LAW. 631, 632 ("Nonprofit directors and officers generally operate under the same legal standards under state law in terms of managerial obligations and the duties of loyalty and care as their for-profit peers."); but cf. Goldschmidt, supra note 44, at 639-40 ("The ALl's formulation [of principles of for-profit corporate govemance] should be marginally modified in the nonprofit context, for example, to take specific account of a nonprofit's mission. . ."). Cf. A.L.I. PRINCIPLES $\S 320 \mathrm{cmt}$. (e) (noting that "the governing board's responsibility to define and advance the charitable purposes includes the obligation to alter the charitable mission, if not the purpose, when warranted." Hence, "these Principles reject the concept of a separate "duty of obedience" when that phrase is used to denote fidelity to the purpose of the charity as originally set forth in the organizational documents.").

As his subtitle suggests, Kurtz identified the duty of obedience in the context of nonprofit organizations; here I trace parallels in the law of private trusts. Cf. Sasso, supra note 6, at 1520 ("The first two duties [care and loyalty] exist in for-profit corporate law while the third [obedience] is unique to the not-for-profit sector."). 
the purposes of the trust, unless such sale is forbidden in specific words by the trust or it appears from the terms of the trust that the property was to be retained in specie in the trust." 45

A further provision of Aunt Essie's will, however, directly implicates this latter exception, complicating matters immensely. With this provision we encounter the trustee's third duty, the duty of obedience. In this case, that duty will preclude doing the Wal-Mart deal. Here is the problematic language:

During the term of this trust, the South Forty shall not be sold and shall not be used for any non-agricultural purposes.

Puzzled by the prohibition on sale of the South Forty, Northrop consults a note that Aunt Essie placed in the same envelope as her will. Heading the note are words that Northrop immediately recognizes as Aunt Essie's favorite line from her favorite movie, Gone With the Wind: "Land is the only thing that matters." She has apparently pondered this line as often as she has repeated it, for, on the page below it, she has given her midrash:

Having lived through the Great Depression, with the stock market crash and the collapse of banks, I have come to believe that land is the only truly secure investment.

Having read Aristotle, the Torah, Thomas Aquinas, and The Ethical Investor, I have come to believe that lending money at interest is evil.

Relying on the same authorities, along with the novels of Sir Walter Scott and the Great Work of Margaret Mitchell Herself, I have come to believe that living off the fruits of farmland is especially virtuous.

Based on my own long and happy life, I have come to believe that living on a farm is the ideal form of human existence.

From the sum of my readings and other life experience, $I$

45 See RESTATEMENT (SECOND) OF TRUSTS § 190; see also RESTATEMENT (SECOND) OF PROPERTY, ch. 4, introductory note (citing RESTATEMENT (SECOND) OF TRUSTS $\S 190$, and stating that "[t]he rules stated in this Chapter in regard to the validity of disabling restraints and forfeiture restraints do not apply to equitable interests under a trust to the extent that the rules of this Chapter are more restrictive than the corresponding rules stated in the Restatement, Second, of Trusts."). 
have come to believe that living on, or at least from the proceeds of, one's ancestral acres is supremely virtuous, the highest form of human excellence.

Now, therefore, I direct the trustee to whom I devise the land described in my will as the South Forty to hold that land for the trust's beneficiaries in strictest accord with these principles. This is why I have directed that the South Forty not be sold or used for non-agricultural purposes during the term of the trust in which I have placed it. ${ }^{46}$

Faced with this document, Northrop would most probably not be able to sell the South Forty to Wal-Mart. ${ }^{47}$ For the purposes of our analysis of dead hand control, it is important to see why.

Notice, again, that the sale would almost certainly not violate the baseline duties of either care or loyalty. With respect to the latter, as we have seen, Northrop has, with some reluctance, forgone essentially the same deal, on his own behalf, with the North Forty. There is, accordingly, no hint here of the trustee's dealing against the interest of the trust beneficiaries for anyone else, least of all himself. With respect to the duty of care, the legitimacy of the sale is equally clear. Indeed, in terms of the classic statement of that duty, this is a paradigm case: in the handling of trust assets, a trustee is to deal as a reasonable person would with his own property. ${ }^{48}$ Here again, Northrop would like nothing better than to do this deal for his own account, and there is everything to indicate that, as a matter of sound asset management, it is an entirely appropriate move. The problem with this sale, then, lies not with the duty of loyalty or care, but with the duty of obedience.

46 Cf. RestatemENT (SECOND) of TRusTs $\S 190 \mathrm{cmt}$. d ("It is less difficult to find a power to sell land purchased by the settlor for purposes of investment than it is to find a power to sell land which was occupied by the settlor and his family as a residence, especially where the beneficiaries are members of the family, since a settlor is more likely to desire that the residence be retained.").

47 See RESTATEMENTS (SECOND) OF TRUSTS $\$ 190 \mathrm{cmt}$. f, illus. 5 (trustee not permitted to sell farm devised in trust, with direction to pay income to life tenant and to convey farm itself to a remainderman, with explicit prohibition on sale, even if "a net income of $\$ 1000$ is received from the farm but it appears that the farm could be sold for a price which would yield an income of $\$ 2000 . ")$.

48 See BOGERT, supra note 39, at 334 ("In the management of the trust the trustee is bound to display the skill and prudence which an ordinarily capable and careful man would use in the conduct of his own business of a like character and with similar objectives to those of the trust."); see also Perpetual Trust, supra note 18, at 1336.(succinctly describing evolution of the modern "prudent investor" rule of the Restatement and the Prudent Investor Act from the more restrictive "prudent man" rule of earlier common law). 


\section{(2) The Duty of Obedience and Dead Hand Control}

Several significant aspects of the duty of obedience are evident in this example. First, that third duty overlaps with the other two duties, care and loyalty, in ways that cast light on the essence of all three. ${ }^{49}$ To see this overlap, it is helpful to distinguish, at least provisionally, between substance or ends and form or means. The duty of loyalty has mostly to do the substantive question of who benefits from the trust. To paraphrase, if not profane, Aunt Essie's catechism, ${ }^{50}$ the chief end of the trust, and hence the chief duty of the trustee, is to benefit the beneficiaries. This is the most basic, even tautological, of all possible substantive provisions: the beneficiaries shall benefit, and no one else, neither the trustee nor third parties. ${ }^{51}$ The duty of care, by contrast, is ancillary and formal; it deals, not with who benefits from trust assets, but with how those assets are managed. It sets a floor on the means of administering trust assets for the benefit of trust beneficiaries: manage trust assets (for the benefit of trust beneficiaries) at least this well, and no worse.

The duty of obedience covers substance and form, ends as well as means, and thus the same ground as both the duty of loyalty and the duty of care. Thus, in Aunt Essie's trust for Sutherland's family, she has specified a particular way of investing the corpus of the trust. It is to be in land, not in stocks or notes or bonds, because, in her view, land is more secure. In specifying her preference for this particular kind of investment, Aunt Essie has altered the baseline standard of care. ${ }^{52}$ On the one hand, she has required what she thinks is a supersafe investment, safer than what the duty of care ordinarily requires. On the other hand, by requiring that the trustee hold a particular piece of land, she has precluded diversification, even in the real estate market, thus permitting an investment that would otherwise almost certainly fall below contemporary investment standards. ${ }^{53}$

The duty of obedience can similarly modify the basic duty of loyalty. Under the common law rule, for example, a trustee cannot

${ }^{49}$ I have explored the duty of obedience in more detail Rob Atkinson, "Rediscovering the Duty of Obedience: Toward a Trinitarian Theory of Fiduciary Duty," Address at the University of Heidelberg Max Planck Institute for Foreign Private and Private International Law Conference: Comparative Corporate Governance for Nonprofit Organizations (July 7, 2006).

so Westminster Shorter Catechism, Answer 1 ("The chief end of man is to glorify God and fully enjoy Him forever.").

S1 BOGERT, supra note 39 , at 341-42.

52 See Brody, supra note 43, at 1485 ("a donor can restrict or enlarge the trustee's investment powers.").

${ }^{33}$ See BOGERT, supra note 39, at 385 (listing diversification as a relevant factor in trustee investments). 
engage in self-dealing transactions with the trust's assets. ${ }^{54}$ Aunt Essie could loosen this restriction by, for example, explicitly permitting Northrop to rent the South Forty from the trust. On the other hand, under the common law rule, trustees are entitled to reasonable compensation. ${ }^{55}$ Aunt Essie could tighten this permission either by setting Northrop's compensation at a below-market rate or by forbidding him any compensation at all. ${ }^{56}$ The duty of loyalty, at a substantive minimum, requires that the trust property benefit the trust beneficiaries; the duty of obedience may require the trustee to confer those benefits in specified forms. Here, Aunt Essie wants to confer what she sees as the benefit of living on, or at least on the income of, a farm. In a more typical provision, she might have specified that the trustee make distributions from the trust only for educational or health care purposes.

Notice, too, that the duty of obedience does not merely alter the baseline duties of loyalty and care; it also alters them in a particular direction, toward the special, the individualized - the subjective, even the idiosyncratic. To see how this is so, consider, again, the fiduciary relationship of guardianship. There, one person cares for another, but under objective, "reasonable person" standards set and applied by the living agents of the law. In trust law, as in the law applicable to other fiduciaries like corporate directors and officers and garden variety agents, the baseline levels of the duties of care and loyalty can, within limits, be custom-made. ${ }^{57}$

Furthermore, the overlap of the duty of obedience with the duties of care and loyalty can seri,usly blur the distinction between substance and form. The duty of loyalty, as we have seen, is essentially substantive; the duty of care, essentially formal. The duty of obedience, by contrast, often inextricably combines elements of both substance and from. Thus, for example, a settlor's preference for holding farmland can be both administrative, to secure the capital asset, and substantive, to provide certain perceived benefits, the virtues of rural living, or at least living in the rentier class. As we have seen, security of investment is not Aunt Essie's only reason for insisting that the South Forty not be sold. For her, investment in real estate, especially this particular real estate, is not just a means to ensure the wherewithal to benefit Sutherland's family; it is part and parcel of that benefit.

\footnotetext{
54 Id. at 344-45.

ss RESTATEMENT (THIRD) OF TRUSTS $§ 38$ (1).

s6 Id. cmt. $\mathrm{e}$.

57 See Atkinson, supra note 49.
} 
Most significant for our analysis is the locus of these idiosyncratic, hybrid restrictions that comprise the duty of obedience. In the case of trusts, as opposed to all other fiduciary relationships, these restrictions can be held by the dead. The law frequently recognizes one person's right to exercise idiosyncratic preferences about the use of assets in the hands of another; that, one might say, is what the entire body of private servitudes law and public land use regulation is about. We have seen an example of that already, with respect to the West Forty. Aunt Essie gave Northrop and Sutherland the power to forbid the fee owner of the West Acre to use that land for anything but farming.

It is the difference between that case and this, between the farming restrictions on the West Forty and the South Forty, that is essential for purposes of our analysis. There, the idiosyncratic veto power was held by living people, Northrop and Sutherland, who could freely trade it to reflect their own preferences in light of current market conditions and, hence, opportunity costs. Here, by contrast, the idiosyncratic preference is held, in effect, by someone who is dead. ${ }^{58}$ Here, therefore, we have dead hand control in its purest form. Only Aunt Essie can consent to the sale of the South Forty to Wal-Mart, and Aunt Essie is dead. ${ }^{59}$

Nothing better illustrates this aspect of the duty of obedience and its relation to dead hand control than its absence. In England and a minority of American jurisdictions, the beneficiaries of a private trust can, by unanimous consent, compel the trustee to modify, or even terminate, the trust. ${ }^{60}$ Were that rule applicable to the trust Aunt Essie established for Sutherland and his children, they, together, could not merely permit, but even require, Northrop to sell the South Forty to Wal-Mart. In effect, under the English rule, Sutherland and his children could accomplish with respect to the South Forty exactly the

${ }^{58}$ The leading clase precluding alteration of trusts by the consent of fully competent adult beneficiaries is Claflin v. Claflin, 20 N.E. 454 (Mass. 1889).

$59 \mathrm{Id}$. at $\S 5$ (comparing trusteeships to other fiduciary relationships and point to other distinctions, including technicalities of title). This distinctive feature of trusts can be traced even deeper, to the very structure of the trust itself. In the ordinary operation of law, adults without seriously defective mental capacity are given control of their own property; minors and incapacitated adults are placed under the guardianship of others, typically parents in the case of minors and close relatives in the case of incompetents. In the trust arrangement, by contrast, property in which competent adults have the beneficial interest can be placed outside their control and in the control of those designated, not by the law, but by the settlor, a private individual. This aspect of certain trusts infuriated John Chipman Gray. See GRAY, RESTRAINTS ON THE ALIENATION OF PROPERTY $\$ 261$, at 246 (2d ed. 1895) ("The common law has recognized certain classes of persons who may be kept in pupilage, viz. infants, lunatics, married women; but it has held that sane grown men must look out for themselves-that it is not the function of the law to join in the futile effort to save the foolish and the vicious from the consequences of their own vice and folly.")

${ }^{60}$ RESTATEMENT (THIRD) OF TRUSTS $\S 65 \mathrm{cmt}$. a; BOGERT, supra note 39 , at 542-44. 
same result that Northrop and his children could accomplish with respect to the North Forty (but for Northrop's duty to prefer Sutherland's family as their trustee).

Requiring unanimous consent, of course, means that a single beneficiary can veto the deal, leaving things as Aunt Essie meant for them to be. Even so, the English rule marks a subtle but fundamental shift of control. Under the English rule, Aunt Essie's will with respect to the land is only done if at least one living person insists on it. Thus, under that rule, the dead hand is constrained by the living, who can, in effect, lift it.

The majority of American jurisdictions, as we have said, generally concede much more control to the dead hand. ${ }^{61}$ There are, as you would expect, some exceptions; sometimes, even under the majority rule, the interest of living beneficiaries trump the directions of dead benefactors. As we shall see in the next section, however, even these exceptions are extremely protective of dead hand control. ${ }^{62}$

\section{(3) The Narrow Passes Around the Duty of Obedience}

The two exceptions to the majority American rule of dead hand control ironically underscore the very strength of the dead hand's grasp. Each is, in its own terms, quite narrow, and, despite their favor with commentators and reformers, neither has enjoyed wide adoption by courts or legislatures. What is more, insistent settlors, without being particularly clever, can almost certainly barricade both passes.

(i) Weighing Beneficiaries ' Current Interests Against Settlors' Original Purposes (with the Settlor's Thumb on the Scales)

Under the first exception, by unanimous consent, all the beneficiaries of a trust can compel the termination or modification of a trust, even if that would be inconsistent with a material purpose of

61 To call this the American rule, as opposed to the English rule, does not quite tell the whole story. The English rule is also the Commonwealth rule; the Claflin position is "a uniquely American rule of equity." Peter J. Wiedenbeck, Missouri's Repeal of the Claflin Doctrine, 50 Mo. L. REV. 805, 808. (1985). It is worth noting, too, where the American rule had its origins. See, Perpetual Trust, supra note 18, at 1329 ("We have to discard the nineteenth-century idea, developed largely in ancestor-worshipping Massachusetts ("where the Lowells talk to the Cabots, and the Cabots talk only to God'), that trusts are written in stone by an omniscient settlor.").

62 There has, to be sure, been some movement of late in the direction of loosening dead hand control in this context. See Perpetual Trust, supra note 18, at 1320 ("Recently, the American Law Institute and the Commissioners on Uniform State Laws have taken steps to relax the Claflin doctrine". . steps which, if adopted, would give courts "much greater latitude in modifying trusts than they have now under the Claflin doctrine.") But, as we shall see, this movement has been modest at best and has left the essentials of the older doctrine largely intact. See id. at 1329 (noting that the reformers "pour new wine in old bottles"). 
the trust, but only if a court determines that "the reason(s) for termination or modification outweigh the material purpose. ${ }^{.63}$ The deference this exception pays to the rule of dead hand control is deeper than it first appears. What looks, at first glance, to be a simple balancing test proves, on closer inspection, to be a scale doubly weighted in favor of the settlor's dead hand.

In the first place, it is the intent of the settlor that determines what purpose is material. Although "material purposes are not readily to be inferred," ${ }^{64}$ a settlor's statement that a purpose is material is controlling. ${ }^{65}$ Here Aunt Essie left little doubt that each of the restrictions on the South Forty is material; if more were needed, she need only to have been more explicit. Materiality, in other words, is measured by a subjective, not an objective, standard. The donor need only be clear about what she considers important; what she considers important may, by any objective standard, be relatively trivial. ${ }^{66}$

In the second place, it seems that the balance to be struck is not the one that a reasonable person would strike, having weighed the benefits of change to the beneficiaries, on the one hand, against the cost of the change in terms of frustrating the settlor's material purpose, on the other. Rather, the balance seems to be that which the settlor would have struck between these two competing concerns. Here again, the test is thus subjective, rather than objective; here, even more, the effect is to make the settlor's wishes dispositive.

Selling the farm to Wal-Mart would not necessarily undermine several of Aunt Essie's purposes. To the extent she was worried about Sutherland's managerial skills, the court could order the proceeds of the sale kept in trust, managed, as before, by Northrop. To the extent she believed, as an administrative matter, in the super-security of investment in agricultural land and, as a substantive matter, in the moral superiority of rental income over interest or dividends, the court could require that the proceeds from the Wal-Mart sale be invested in other farmland. But the sale would be directly at odds with another of her substantive purposes, having Sutherland and his children receive income, not just in the form of farm rent, but also in the form of rent from ancestral lands.

That latter purpose, of course, is quite quirky, if not perverse. But to say that is merely to invoke objective, as opposed to subjective,

63 RESTATEMENT (THIRD) OF TRUSTS $\S 65$ (1) and (2).

${ }_{64}$ Id. cmt. d.

${ }_{65}$ Id.

${ }_{66}$ The Uniform Trust Code lacks even this modest measure of donor restraint. See Alan Newman, The Intention of the Settlor Under the Uniform Trust Code: Whose Property Is It, Anyway?, 38 AKRON L. REV. 649, 661 (2005). 
standards of moral merit. Aunt Essie obviously thought otherwise, and, as we have seen, the law of private trusts indulges her preference (although, it bears repeating, only in America).

(ii) Accommodating Novel Circumstances to Favor Beneficiaries (But Only When That Furthers the Settlor's Original Purposes)

The second orthodox exception to the general rule of dead hand control is, if anything, even less favorable to the interests of the living. In the words of the Restatement,

The court may modify an administrative or distributive provision of a trust, or direct or permit the trustee to deviate from an administrative or distributive provision, if because of circumstances not anticipated by the settlor the modification or deviation will further the purposes of the trust. ${ }^{67}$

The comment to this section makes clear that it can operate to remove restrictions on the sale of an asset. "Thus, for example, the provision subject to modification or deviation may be one expressly directing or expressly forbidding the sale of certain properties. . . ."68 But the commentary explicitly treats such restrictions as administrative, not as substantive. ${ }^{69}$ The terms of the rule itself cover not only "administrative" but also "distributive" provisions; presumably Aunt Essie's normative preferences for ancestral farm rent, as well as her prudential convictions about the security of farmland, could be overridden here.

But, here again, the standard for overriding those preferences seems to be, not the net gain to the beneficiaries, but the oddly imponderable preferences of Aunt Essie herself. ${ }^{70}$ And, what is more, this latter exception is triggered only by circumstances the settlor has not foreseen. In Aunt Essie's case, it seems pretty clear that she foresaw, and rejected, the prospect at hand. Even savvier settlors may press this exception to the absolute minimum, with a Heraclitian catch-all clause stating that they have foreseen the prospect, not merely of specific changes, but of universal mutability, and decided that they prefer their own preferences to all alteration in the face of any change. ${ }^{11}$

\footnotetext{
67 RESTATEMENT (THIRD) OF TRUSTS $§ 66$ (1).

68 Id. at comment. b.

69 Id.

70 See, e.g., In re Weston's Settlements, 3 ALL E.R. 338 (1968) (refusal to alter for tax advantages a trust that required its beneficiaries to remain residents of England).

1 Jonathan R. Macey, Private Trusts for the Provision of Public Goods, 37 EMORY L.J.
} 
Both exceptions to dead hand control, then, seem, on the surface, to curb excessive costs to beneficiaries of eccentric settlor preferences, whether formal or substantive. But the measure of excessive eccentricity, in both cases, is itself ultimately a matter of the settlor's own preference. That makes the orthodox exceptions to dead hand control more a mirage than an alternative route. Exceptions can be made in exceptional circumstances (but only if the settlor wouldn't have taken exception).

\section{d. Aunt Essie's Real Will: Dynastic Ambitions and the Dead Hand}

Aunt Essie, as we have seen, took great pains, in both her inter vivos and testamentary dispositions, to take care of her family and her farm after her death. But, truth be told, those dispositions are only the barest tip of the proverbial iceberg. In fact, Aunt Essie had far deeper, more ambitious plans for both her family and her farm. To see just how deep and ambitious those plans were, we must reconstruct a conversation she had with her lawyer in the course of her estate planning. This conversation will reveal significant limits on the extent of dead-hand control in the case of property passed into private, as opposed to charitable, hands.

Stated starkly, Aunt Essie's ambition came to this: She wanted her farmland to stay in the hands of her family forever. More specifically, she wanted to make sure that the North Forty and the South Forty, respectively, remain permanently in the hands of Northrop and Sutherland's branches of the family. To some extent, she derived this ambition from an aggressively literal reading of the Book of Leviticus, especially its provision for the Year of Jubilee; ${ }^{72}$ to a larger extent, she developed it in the course of her life-long love of Jane Austen novels, filled as they are with fees tail, strict settlements, and estates in coparceny. ${ }^{73}$

When she approached her lawyer with this plan, he gave a long and accurate historical answer, recounting the various ways this had once been possible. For our purposes, however, we need only his conclusion: it cannot be done today. ${ }^{74}$ Stated more formally, any splitting of interests in real or personal property among individuals

295, 307 (1988).

${ }^{2}$ Leviticus 25:8-34 (provision for the return of ancestral lands to the families of original holders every fifty years).

73 See Margaret Valentine Turano, Jane Austen, Charlotte Bronte, and the Marital Property Law, 21 Harv. Women's L.J. 179 (1998).

74 See, e.g., Newman, supra note 66, at 672 ("Historically, restraints by the donor of property on its alienability by the donee generally were not valid.") (citation omitted). 
who hold their interests in their individual capacities can be re-united by their joint action into a single, full, and immediately transferable title.

But what of those who hold interests in a fiduciary capacity, not in an individual capacity? Trustees of private trusts must, as we have seen, honor the donor's intent, across a wide range of forms of control, for the duration of the trust. What is more, they cannot, alone or with the trust's beneficiaries, hasten the termination of the trust. Here the common law has been more generous toward dead hand control, but, in the grand scheme of things, only slightly.

The key is the legal limit of the life of a private trust. The beneficiaries of any private trust must be known within twenty-one years after the death of identifiable individuals alive at the trust's creation. This is the famous-or notorious-Rule Against Perpetuities. More precisely, this is the Rule Against Private Perpetuities. Here, of course, is a significant difference between private and charitable trusts: the latter can last only for a generation beyond the Rule's "lives in being plus twenty-one years"; the latter can last, literally, forever.

This distinction between private and charitable trusts may be fast disappearing for most family trusts like Aunt Essie's. A large minority of states have effectively repealed the traditional rule against perpetuities, making possible almost precisely the unending dynastic trust of Aunt Essie's dreams. ${ }^{75}$ But even here, at least for her, there is a hitch. Statutes repealing the traditional rule almost invariably require that any real property in the trust be subject to immediate sale by the trustee. ${ }^{76}$ Thus, had even the virtually eviscerated new rule been available to her, Aunt Essie would have to have chosen between controlling the use of her farm for several generations, under the old rule, and controlling the use of its economic value forever, under the new. Only by placing her land in a charitable trust, as we shall see in the next section, could she control its use forever.

\section{e. Summary}

In this section, we have seen that restrictions imposed by the dead hand are relatively routine in the non-charitable sector. Only in the case of transfers in trust, however, is the exercise of these restrictions in any real sense left in the control of anyone other than the living.

75 Perpetual Trust, supra note 18; see also Newman, supra note 66, at 655-56; Verner F. Chaffin, Georgia's Proposed Dynastic Trust: Giving the Dead Too Much Control, 35 GA. L. REV. 1 (2000).

76 Perpetual Trust, supra note 18, at 1313-14. 
And, even with respect to dead hand control of assets held in trust, dead hand control has, at least traditionally, been temporally limited by the rule against perpetuities, which, even in its most radical statutory revisions, continues to free land after, at most, a few generations. Against this background, we can now better understand dead hand control in the charitable sector. Only here, we shall see, does the law allow the dead hand of donors to reach infinitely far into the future, with a grip that the living may never be able to loosen.

\section{Dead Hand Control Inside the Charitable Sector}

As soon as we move from the private to the charitable sector in our survey of dead hand control, we note a basic, and somewhat surprising, asymmetry. Aunt Essie, as we have seen, left some property to private individuals outright and some in trust. Thus, Northrop and his family received their respective interests in the North Forty, present and future, outright, in their individual capacities; Sutherland and his family, by contrast, received their interests in the South Forty in trust.

In turning to Aunt Essie's charitable dispositions, we might expect to find the same pattern; in fact, at this critical point, the parallel between private and charitable gifts breaks down a bit. Unlike some private gifts, those to individuals in their individual capacities, all charitable gifts are subject to fiduciary duties. The question here is what those duties are. They always include the duties of care and loyalty; more sharply focused, then, the question is whether, and to what extent, they are subject to a duty of obedience, and what that duty, if applicable, entails. To address those issues, we must look at two very different kinds of charitable gifts: those that are subject to explicit conditions, and those that are not.

\section{a. Gifts to Charity Without Explicit Conditions}

Gifts to charity without explicit conditions come in two contrasting yet complementary kinds, unconditioned gifts of legal conditions and implicitly limited gifts without explicit conditions. In the former, dead hand control is almost ways more apparent than real; in the latter, dead hand control is often more real than is apparent.

\section{(1) The Paradox of Unconditional Gifts of Legal Conditions}

To appreciate the apparent paradox of this kind of gift, consider two final twists in the subplot of the West Forty. Aunt Essie sold that parcel, you will recall, to her brother Wesley, subject to a condition 
that it be used only for agricultural purposes. That veto over nonagricultural purposes passed under her will to her nephews, Northrop and Sutherland. By putting their interests together, we have seen, Uncle Wesley, Northrop, and Sutherland can convey to Wal-Mart unrestricted title to the West Forty. What we need to see here is that, if a charity held either of those two interests, the possessory fee interest of Wesley or the forfeiture provision of Northrop and Sutherland, the charity could do the very same deal.

Consider, first, the fee interest that Aunt Essie sold Uncle Wesley. Let us suppose that, just before Wal-Mart comes a-calling, Uncle Wesley goes to his reward. A pious but childless Presbyterian elder, he leaves all he has to the Indiantown Presbyterian Church, including his possessory interest in the West Forty. Standing now in Uncle Wesley's shoes, the Church can do exactly the same deal with WalMart, Sutherland, and Northrop that Uncle Wesley himself would have done; indeed, whether or not Uncle Wesley would have done the deal makes no difference.

Consider, next, the other interest in the West Forty, the veto over any non-agricultural use, which passed to Northrop and Sutherland. Suppose that, just prior to her death, Aunt Essie had executed a codicil to her will removing Northrop and Sutherland as residuary takers and replacing them with the Indiantown Presbyterian Church. At her death, the veto would have passed, accordingly, not to her nephews, but to the Church. The Church would be no less free than Northrop and Sutherland to make the sale to Wal-Mart. It is under no more obligation than they, in this case, to maintain the land in agricultural use. Control of the condition imposed on the West Forty would have passed, unconditionally, to the Church.

To unpack this apparent paradox, we need first to recall the difference between holding property interests as a fiduciary, on the one hand, and holding them outright, in one's private, individual capacity, on the other. The private parties who held interests in the West Forty in our first hypothetical-Wesley, Northrop, and Sutherland-are not subject to any fiduciary duties at all. Free of the duty of care, they can make as wise or foolish a deal with Wal-Mart as they are able. Free of the duty of loyalty, they have only their own profit to consider; they can seize the opportunity to sell to Wal-Mart from anyone else in the world, including each other. Free from the duty of obedience, they are under no obligation to consider Aunt Essie's wishes with respect to the West Forty. What's more, they can use the proceeds of the sale in whatever way they wish, subject only 
to the outer limits of the criminal law; they can buy mountain bikes or Humvees if they like, though they can't buy mountains of cocaine.

The Church, by the very fact of its being a charity, never holds anything quite so freely. It always holds property in some fiduciary capacity, subject to the three fiduciary duties of trustees: loyalty, care, and obedience. Thus, under the duty of loyalty, those who are empowered to act for the Church must consider the Church's advantage, not their own, in deciding to sell to Wal-Mart. Thus, for example, were Northrop a member of the Church's governing body, he could not properly vote to exercise the Church's veto over the sale of the West Forty to Wal-Mart in the hope of selling his own land to Wal-Mart. Similarly, under the duty of care, the governing body of the Church would have to consider the overall soundness of the transaction. Before selling the Church's interest in the West Forty to Wal-Mart, they may need to consider what Target and Costco have to offer. And they may need to consider whether having a Wal-Mart Supercenter right down the road diminishes the market value of the Church's other holdings by a greater amount than the Church gains in the sale. But these are the same kinds of factors any sensible investor would consider. Under these two fundamental fiduciary duties, this transaction is, not surprising, like any other.

What is distinctive about this hypothetical has to do with the third duty, that of obedience. That duty, as we shall see below, may well affect what the Church does with the proceeds of the sale $;{ }^{77}$ it may, in cases very similar to this one, affect whether the Church can sell certain assets at all. ${ }^{78}$ In this case, however, the duty of obedience does not bind the Church to keep the West Forty in agricultural use. Whether the Church receives the restricted fee from Uncle Wesley or the fee restriction from Aunt Essie, the Church is not bound, by the duty of obedience, to leave the land in agricultural use.

Dead hands may have passed power over the fate of the West Forty to the Church, but the decision about how to exercise that power is very much in the living hands of the Church's governing body. Nothing in the restrictive language of the deed suggests any purpose other than those we have identified: protecting the value of neighboring parcels and permitting the holders of the restriction to share in the gains from changing the use of the land. ${ }^{79}$ There is no reason to infer a further purpose, preserving the agriculture use as valuable in itself or for any other reason. Nor is there anything about

\footnotetext{
77 See infra Part II.B.2.a (2).

78 See infra Part II.B.2.b.

79 See supra Part II.B.1(a).
} 
the purpose of the Church that would suggest it, any more than any private holder of the restriction, should be bound to any other such purpose.

We shall see, very shortly, that these latter considerations may change, with respect to a very similar set of restrictions. What we need to see here is that some forms of dead hand control, applicable to but avoidable by private individuals, are no less applicable to and avoidable by charities.

The paradox of unconditional gifts of legal conditions thus disappears once it is unpacked. Sometimes conditions on the use of assets are not meant to bind a charity to these conditions themselves. Rather, such conditions are subject to the charity's discretion; the charities discretion is not subject to these conditions.

This situation is doubtlessly unusual in practice, and serves us primarily to distinguish and illuminate two much more common, and much more troubling, situations. These are implicit conditions on apparently unconditional gifts, which we deal with in the remainder of this section, and explicit conditions on gifts, which we take up in the next section.

\section{(2) The Problem of Implicit Conditions on Unconditional Gifts}

Sometimes, as we saw in the last example, a condition that seems to restrict a charity in its use of assets does not, as a matter of law, have that effect. Here we consider the opposite situation: Gifts that have no explicit conditions are nevertheless sometimes found to be subject to such restrictions. To see how this latter situation arises, consider another clause in Aunt Essie's will, her specific bequest of $\$ 500,000$ to the Indiantown Presbyterian Church's day care and kindergarten program.

Aunt Essie never had any children of her own. Despite that (perhaps because of that), she took very much to heart the interests of the children of the Indiantown community, particularly those raised, as she herself was, in the Indiantown Presbyterian Church. Accordingly, she bequeathed $\$ 500,000$ to the Church's day care and kindergarten program; significantly, for purposes of our analysis, this bequest is subject to no explicit restrictions.

By the time Aunt Essie executed her will, the church elders had incorporated the Church's pre-school programs as a separate charitable organization, governed by a board of directors appointed by the elders and organized as a 509 (a)(3) supporting organization. Some said this showed a distinctly un-Presbyterian distrust in divine providence; the elders insisted that God helps those who help 
themselves. Whatever the merits of their respective theological positions, the elders and their critics agreed on the anticipated legal consequences: to insulate the Church from any legal liability for accidental harm to children in the program.

Aunt Essie's $\$ 500,000$ bequest duly passed through her estate to the board of directors of the kindergarten program. By a unanimousand enthusiastic-vote, they devoted it to construction of a new, state-of-the-art child care facility. The facility has been an exceptional success. Enrollment is high among Presbyterians and nonPresbyterians alike, and parents and children are uniformly enthusiastic.

Now Wal-Mart wants to buy them out. The Board believes this is in the best interest of the children of the community. Parents of most children pay fees that cover the full cost of care; those who cannot afford the full price attend for free under a generous, but thinly stretched, scholarship scheme. If the kindergarten program were operated by Wal-Mart, the cost of tuition would likely stay the same, or even drop, owing to Wal-Mart's astounding economies of scale. Fee-paying parents would thus be no worse off, at least in terms of out-of-pocket cost. More significant, in the Board's view, is the likely effect on scholarship families. Sale of the program to Wal-Mart would provide capital for a number of endowed scholarships. The Board, accordingly, is eager to do the deal, as are the parents of all the present and prospective students.

There have, however, been two dissenters: Northrop and Sutherland. They claim that, upon the sale of the facility to Wal-Mart and the cessation of the Church's active operation of a kindergarten of its own, the purpose of Aunt Essie's bequest would be frustrated and the funds should pass, under the residuary clause of her will, to them. American courts are badly divided on their treatment of such claims, and both identifiable lines of authority are, it is fair to say, seriously muddled. ${ }^{80}$

80 See Evelyn Brody, Whose Public? Parochialism and Paternalism in Charity Law Enforcement, 79 IND. L.J. 937, 946, 956-68 (2004) (discussing the relevance of whether the charity is formally organized as a trust or as a nonprofit corporation); Evelyn Brody, Charitable Governance: What's Trust Law Got To Do With It, 80 CHI.-KENT L. REV. 641 (2005); Brody, The Limits of Charity Fiduciary Law, supra note 43, at 1458-76 (1998); Atkinson, Unsettled Standing, supra note 6 at 689-92 (1998) (same). See also Robert A. Katz, Let Charitable Directors Direct: Why Trust Law Should Not Curb Board Discretion Over a Charitable Corporation's Mission and Unrestricted Assets, 80 CHI.-KENT L. REV. 689 (2005); A.L.I. PRINCIPLES $\S 200 \mathrm{cmt}$. (b) ("[A] trust instrument cannot be varied without court approval (unless the instrument provides a nonjudicial process to make the desired amendment), whereas the corporate board . . . ha[s] greater autonomy in adjusting to unanticipated circumstances (with protection for restricted gifts)."); id. \$ 400, Reporter's Notes. 
According to the less restrictive approach, ${ }^{81}$ no special conditions are to be inferred. Thus, in our example, Aunt Essie's will would be read to impose no restrictions on how the pre-school program uses the funds. The only limit is extraneous to her will; it lies in the powers of the Board itself, as spelled out in its organizational documents. If, as is often the case, the pre-school's organizational documents contain boilerplate language allowing it to undertake any charitable activity, then the Board can not only do the deal with Wal-Mart, but also do the deal without forfeiting Aunt Essie's bequest to Northrop and Sutherland. ${ }^{82}$

According to the other line of authority, even gifts without explicit restrictions, like Aunt Essie's bequest to the pre-school program, are nonetheless subject to an implicit restriction to the purposes of the organization at the time the gift was made. ${ }^{83}$ In Aunt Essie's case, a court taking this position would find that her bequest contained an implicit condition that the money be used for the stated purpose, supporting a pre-school, subject to forfeiture, as asserted by Northrop and Sutherland, should the donee organization alter the gift's purpose. This more restrictive approach leads, logically, to treating unconditional gifts to charity basically the same as explicitly conditioned gifts, the subject of the next section.

\section{b. Gifts to Charity with Explicit Conditions}

To appreciate the full power of the dead hand over charitable assets, we must examine gifts made to charity subject to explicit conditions. Here the parallels with respect to private gifts in trust are particularly illuminating. On the one hand, the kinds of control that can be exercised are essentially the same, and the modes of removing these controls are functionally very similar, if doctrinally distinct, and extremely limited. Yet in charity, in contrast to private trusts, the rule against perpetuities has essentially no role. Dead hand restrictions on charitable assets, as on assets in private trusts, are demonstrably difficult to remove. What's more, dead hand control in the realm of charity, unlike its counterpart in the purely private sector, has no

${ }^{81}$ See A.L.I. PRINCIPLES $\S 400$ (c) ("A gift without any terms may be used for any purpose of the charity, including a charitable purpose that did not exist at the time of the gift.")

82 See Brody, The Limits of Charity Fiduciary Law, supra note 43, at 1461 ("The newpurposes problem could obviously be avoided by including in the initial articles of incorporation a statement that the charity is formed 'for any charitable purpose."').

83 A.L.I. PRINCIPLES $\$ 240 \mathrm{cmt}$. (a) ("some courts have held that even unrestricted gifts, as well as earned and investment income, are impressed with the pre-amendment purposes of a donee charity."). See Boisture \& Varley, supra note 4, at 227 ("The directors of a nonprofit charitable corporation-like the trustees of a chartable trust-must obtain prior court approval in a cy pres-like proceeding for any fundamental change in corporate purposes."). 
systematic sunset provision. To illustrate these similarities and differences, we need to consider Aunt Essie's devise of the East Forty to the Church, which is strikingly like her devise of the South Forty in trust to Sutherland's family.

Here again, we begin with Wal-Mart at the door, wanting to buy farmland for a Supercenter. They have considered, in turn, the West Forty, the North Forty, and the South Forty. The sale of the West Forty is imminently doable as a quadrilateral transaction between Wal-Mart as buyer, Uncle Wesley as seller of his fee interest, and Northrop and Sutherland as sellers of their veto rights. But Northrop and Sutherland would prefer to cut Uncle Wesley out, and Northrop would like to cut out Cousin Sutherland as well. Northrop himself, however, is constrained, not by his better self, but by his fiduciary duty. He has, accordingly, considered cutting himself out and selling the South Forty to Wal-Mart, for the benefit of Sutherland and his family. As we have seen, the trust for Sutherland and his family effectively precludes that sale. ${ }^{84}$

While Uncle Wesley and his nephews plot with and against each other, Wal-Mart's agents have been eying the last quadrant of Aunt Essie's farm, the East Forty. Once again, however, Wal-Mart's lawyers have found a cloud on the title. Tracing the Church's title back through Aunt Essie's executor, they find the following language in her will:

The East Forty to the Indiantown Presbyterian Church, to hold for the benefit of its members and particularly for its retired ministers, as a retirement home and park.

During the term of this trust, the South Forty shall not be sold and shall not be used for any purposes other than agricultural, parkland, and single-family residential purposes.

Inquiring of the Church elders what Aunt Essie might have meant by these provisions, Wal-Mart's lawyers, like Northrop before them, discover a set of additional instructions, also written in Aunt Essie's own hand and placed in the same envelope as her will:

${ }^{84}$ What is more, Northrop and Sutherland may face another problem. If either is a trustee of the Church, he may be bound, here again, by the duty of loyalty, because the Church itself has land that Wal-Mart would be equally happy to buy: the East Forty. 
Having lived through the Great Depression, with the stock market crash and the collapse of banks, I have come to believe that land is the only truly secure investment.

Having read Aristotle, the Torah, Thomas Aquinas, and The Ethical Investor, I have come to believe that lending money at interest is evil.

Relying on the same authorities, along with the novels of Sir Walter Scott and the Great Work of Margaret Mitchell Herself, I have come to believe that living off the fruits of farmland is especially virtuous.

Based on my own long and happy life, I belief that living on a farm is the ideal form of human existence.

From the sum of my readings and other life experience, $I$ have come to believe that having clergy-folk, active and retired, living near the houses of worship, particularly within walking distance, is supremely and mutually advantageous.

Now, therefore, I instruct the Church to hold the East Forty, which I have devised the Church in my will, in strictest accord with these principles. In particular, it is my intention that the Church never sell the East Forty.

This language, of course, closely parallels the language of the trust that Aunt Essie's will set up for Sutherland's family. ${ }^{85}$ Faced with this document, the Church with respect to the East Forty, like Northrop with respect to the South Forty, would almost certainly not be able to sell to Wal-Mart. Here, as there, the problem is the duty of obedience, not the duty of care or the duty of loyalty. And here, as there, the traditional ways around that duty are narrow to the point of impassability.

The terms of the will itself, even without the gloss in Aunt Essie's note, make clear that this restriction is not just for the benefit of private parties in their private capacities. Whatever its benefits for private persons, this arrangement is also meant to benefit a recognized charity, the Indiantown Presbyterian Church, in recognizably charitable ways. In that respect, it differs significantly from both the use restriction in the deed to the West Forty and the restrictions in the 
trust under which Northrop holds the South Forty for Sutherland. It also differs from another situation we analyzed earlier, that in which the Indiantown Presbyterian Church came to hold the restriction on the development of the West Forty. There, you will recall, the Church, although a charitable organization, had no special duty to enforce the restriction. Here the matter stands quite differently.

The question for the Church is not whether they want to sell the East Forty to Wal-Mart; they are, in fact, quite eager. The question, rather, is whether they can sell it, legally, and whether they should, morally or pragmatically. One element in their calculation is quite clear: it would not be what their benefactor, Aunt Essie, had in mind. We know, well enough, that she wanted this particular farm preserved, in the way that she had long remembered it. What we do not know, however, is what she would have wanted if she fully understood the present situation. That, we shall see, may have a significant bearing on the Church's options.

\section{c. Traditional Means of Removing Dead Hand Control of Charitable Assets}

Traditional doctrine gives two basic ways to remove or modify dead hand control of charitable assets: equitable deviation and cy pres. The former applies to administrative provisions and is fairly permissive; the latter applies to substantive provisions and is fairly strict. To get a sense of their similarities and differences, as well as their scope and limits, it will be useful to see how Wal-Mart and the Church might use these doctrines in the case of the East Forty.

\section{(1) Equitable Deviation}

The doctrine of equitable deviation might serve the Church and Wal-Mart well with respect to several provisions, if they could be read in isolation. Thus, for example, the Church could continue to indulge Aunt Essie's preference for the supposed super-safety of investments in farmland by simply re-investing the proceeds from the sale of the East Forty in another farm. That would even preserve her substantive, ethically-based preference for supporting the trust's beneficiaries with rental income from farming. In those respects, obviously, the doctrine of equitable deviation would work essentially the same as in the case of the private trust for the South Forty, with respect to closely parallel provisions.

Unfortunately for Wal-Mart and the Church, however, Aunt Essie's administrative and substantive provisions seamlessly overlap. Here again, the parallel with her preferences as to the South Forty is 
quite close. She wants the trustee to retain the East Forty not only as a secure investment, but also as beneficial in and of itself. This was also true, you will recall, of her provisions for the East Forty. There, however, the parallel exception allowed for deviation from "distributive" as well as "administrative" conditions. With respect to charity, substantive matters are traditionally handled by a different doctrine, cy pres, under a less generous standard. ${ }^{86}$

\section{(2) Cy Pres}

Modification of substantive restrictions under the traditional doctrine of cy pres requires that three conditions be met. First, and most basically, carrying out the donor's original charitable purpose must have become more or less seriously frustrated. In the words of the Restatement, those purposes must have become "illegal, impossible, or impracticable." 87 Second, the donor must have had not only the particular intent to benefit charity in the original, specific way, but also a broader intent to benefit charity more generally. The third requirement gives the doctrine its short-hand name. In modifying the donor's original, frustrated purpose, the court must hew as close as possible-in Norman French, cy pres comme possible - to the donor's original purpose.

All three requirements are fact-specific and, therefore, subject to a measure of manipulation in particular cases. What is more, all three requirements have, to some extent, been liberalized by various courts or legislatures, ${ }^{88}$ and commentators are virtually unanimous in calling for further liberalization. ${ }^{89}$

It is unlikely, however that the Church's effort to sell the East Forty to Wal-Mart would win judicial approval under any recognizable version of the cy pres doctrine. ${ }^{90}$ The second and third

${ }^{86}$ The Restatement suggests that the doctrine of deviation applies to charitable as well as private trusts. It is hard to see how this could apply to the modification of what it calls "distributive," as opposed to "administrative" terms, without undermining the doctrine of cy pres, which the Restatement places in a separate section and describes as applicable only to charitable trusts. See RESTATEMENT (THIRD) OF TRUSTS $\S 381,399$.

87 RESTATEMENT (THIRD) OF TRUSTS $§ 67$.

88 See, e.g., Newman, supra note 66, at 669 (describing liberalizations under the Uniform Trust Code).

${ }^{89}$ Cf. Eric G. Pearson, Comment, Reforming the Reform of the Cy Pres Doctrine: $A$ Proposal to Protect Testator Intent, 90 MARQ. L. REV 127 (2006) ("Although the modern discourse surrounding the cy pres doctrine argues that the narrow application of the doctrine can result in an ineffective and an inefficient use of trust assets, this Comment makes three proposals to ensure that future settlors can continue to rely upon the judiciary to uphold their intent for many years into the future.").

90 See George G. Triantis, Organizations as Internal Capital Markets: The Legal Boundaries of Firms, Collateral, and Trusts in Commercial and Charitable Enterprises, 117 HARV. L. REV. 1102, 1157 ("The [cy pres] doctrine, however, offers little flexibility because it 
requirements could quite likely be met. From her other gifts to the Church, a court could plausibly infer a general intent to benefit charity more broadly. As we have seen in examining the doctrine of equitable deviation, a court could fairly easily fashion a regime quite close to what Aunt Essie has established. It need only require that the proceeds of the sale of the East Forty be used to purchase a comparable farm, perhaps quite literally near the East Forty itself.

The most serious problem would be with the first and most fundamental condition, the frustration of the donor's original purpose. Aunt Essie's desire to support retired ministers in residence on a specific part of her farm is certainly neither illegal nor impossible. Nor can it be said to be impracticable, without stretching the meaning of that term beyond recognition. The worst that can be said for her original purpose is that something very close to it can be accomplished with a sizeable saving in resources. A retired minister can live in equal comfort on a nearby farm, with a fairly large amount of capital left over for other charitable purposes.

Stepping back from cy pres doctrine, however, one might well believe this latter to be a particularly laudable change, one that would come at very little real cost in anything but the most idiosyncratic, if not self-indulgent, of Aunt Essie's intentions. A bit more boldly, one might wonder why the Church, faced with what it sees as substantially superior uses of very valuable social assets, might not seek other ways to loosen Aunt Essie's dead hand grip. Those are the alternatives to orthodox dead hand doctrine that we explore in the next part.

\section{Summary}

In comparing dead hand control over private and charitable assets, it is helpful to think in terms of the three familiar dimensions: width, height, and length. By width I mean the range of possible kinds of control. As the example of Aunt Essie's will suggests, dead hand control in both sectors covers an extremely wide front that includes matters of form as well as substance. By height I mean the relative difficulty of surmounting dead hand restrictions. Thinking in the other direction along this axis, down rather than up, we ask how deeply the dead hand restrictions are legally embedded and, proportionately, how difficult are they to undermine. With respect to this dimension, the similarity between the charitable and the private sectors is 
striking. Indeed, with respect to administrative matters, the standards for change are essentially identical. With respect to substantive matters, the standards, if not identical, are very similar. In the case of both form and substance, with fairly narrow exceptions, the donor's will is to be done (and it's very hard to undo).

It is in the third dimension, length, that we find the greatest difference. In the private sector, dead hand control is relatively short. Under the traditional Rule Against Perpetuities, private trusts and associated dead hand controls have been legally allowed to last, at the outside, several human generations. In the charitable sector, by contrast, the length of dead hand control is asymptotic toward infinity. Charities can labor under dead hand controls for the rest of human history, or at least for the duration of the American Republic.

When we turn from the descriptive mode of analysis to the normative, we find this latter difference especially significant. The foresight of donors might well be expected to penetrate the future for a generation or two, in public affairs as well as in private, familial matters. ${ }^{91}$ At some measure of remove, however, the prescience of even the wisest of donors must give way to the will, ${ }^{92}$ if not the wisdom, ${ }^{93}$ of the living. Given the stinginess of current doctrine in that regard, even the most patient among us may be forgiven for looking to alternative means of relaxing the dead hand's control.

\section{THE LOW ROAD TO CY PRES REFORM}

At the end of the last Part, we saw problems with the orthodox approach to removing dead hand control in the case of particular charitable uses. With respect to various forms of dead hand control, orthodox means of removal often hit a dead end. This is unfortunate for those of us, practitioners and theoreticians alike, who seek to move charitable assets into what we believe are higher and better public uses; it is particularly unfortunate for those of us who view the freeing of charitable assets as inherently good, independent of the merits of any particular move. In this part, we will see how detours around the dead ends of current doctrine may permit not only greater

91 Hirsch \& Wang, supra note 28, for example, argue that, over a fairly wide range of functional forms, dead hand control in the private sector may well be wealth-maximizing for the period of the traditional Rule. See also Brody, The Limits of Charitable Fiduciary Law, supra note 43 at 1421 ("Courts generally refrain from interfering with the wishes of a private settlor, because of the term limits on the life of a private trust.").

92 I make this case at greater length (and with more qualification) in Atkinson, Reforming Cy Pres Reform, supra note 2.

93 Compare RICHARD A. POSNER, ECONOMIC ANALYSIS OF LAW 556 (5th ed. 1998) (noting consistency of cy pres doctrine with the intent of rational donors) with Macey, supra note 71, (disputing Posner's defense of the economic efficiency of the cy pres doctrine). 
flexibility in resolving particular cases of dead hand control, but also a substantial reduction in the depth and breadth of dead hand control overall. If these alternative routes are taken in enough cases, they become not detours, but the new way.

This part maps out two lower roads to cy pres reform-two practical ways to get around dead hand control. Both lead away from dead hand control, but beyond that common starting point, they branch off in opposite directions. The first, which I call principled practice, leads in the direction of greater autonomy from state control, toward what I call the sectarian model of charitable organizations. ${ }^{94}$ The second, which I call unprincipled practice, would lead us in the opposite direction. It would take us past the roadblocks erected by deceased charitable donors, only to direct us into the desert of something very much worse: state control, even confiscation, of charitable assets. This route thus leads charity, not to the enhanced independence I have recommended, but to the fate best reserved for lemmings.

As we shall see, this latter route is not merely unprincipled in terms of my sectarian model, which advances the principle of charity's freedom from dead hand donor control. It is also abandons two other principles, both of which are much more widely shared. The first of these is the independence of charitable organizations from direct state control, what we might call the Dartmouth College principle. ${ }^{95}$ The second of these is even more deeply rooted and widely shared. It is the principle, enshrined in the Fifth Amendment to the Constitution, that private property shall not be taken for public use without just compensation.

\section{A. Principled Practice}

There is, of course, a principle even more basic than any of these: general compliance with the law itself, at least when it is not manifestly unjust. That principle forms the floor of our principled practice, even as the principle of reducing state-enforced dead hand control is our pole star. Grounded in the former and guided by the latter, we can chart the course of our principled practice. We will begin with a step that is, on the one hand, legally dangerous but radically independent of state involvement; we will end with a step that is perfectly legal but heavily dependent on state action.

94 Atkinson, Reforming Cy Pres Reform, supra note 2, at 1142-48.

95 Trustees of Dartmouth College v. Woodward, 17 U.S. (4 Wheat.) 518, 642 (1819). 


\section{Charities' Acting Unilaterally}

The first step in the direction of charitable independence is elegantly simple, if legally bold: JUST DO IT. Charitable trustees, under this approach, would simply make the change they see fit, without bothering to petition the relevant court under the doctrine of cy pres or equitable deviation. Thus, in our examples, the Church would simply sell the East Forty to Wal-Mart.

This would seem, of course, directly to contravene the duty of obedience, and thus to be doubly dangerous for the charity and its fiduciaries. It would seem to expose charitable trustees to liability for breaching that rule, ${ }^{96}$ and to expose their lawyers to discipline for counseling or assisting in a violation of law. ${ }^{97}$ Upon closer inspection, however, neither danger is so clear. With respect to the trustees, the Restatement of Trusts recognizes an interesting "no harm, no foul" exception to the duty of obedience:

If . . . a trustee (e.g., a recipient institution or community foundation), without prior court authorization, applies property to a purpose other than that designated by the terms of the trust, the trustee is subject to liability for breach of trust. If, however, the application made by the trustee is such as the court would have directed, the court may approve the application, and such approval will be as effective as though the court had authorized the application before it was made. ${ }^{98}$

The trustees' lawyers should enjoy a kind of derivative immunity: If, under this exception, the application they recommend or assist is deemed appropriate, they can hardly be held to have violated their fundamental obligation not to recommend or assist in illegal activity.

96 See Triantis, supra note 90, at $1153 \mathrm{n} .164$ ("On the books, at least, a trustee that participates in the decision to use restricted funds for an unauthorized purpose will be personally liable to restore the diverted money to the trust and might also be dismissed as trustee.") (citations omitted); see also Boisture \& Varley, supra note 4, at 227 ("Where a nonprofit hospital corporation or holding company proceeds, without court approval, with a sale of joint venture transaction that will terminate the nonprofit's hospital operations and redeploy its assets, state courts have the authority both to enjoin the transaction and to hold the nonprofits directors liable for a breach of fiduciary duty."); but cf. Brody, The Limits of Charitable Fiduciary Law, supra note 43 , at 1434 ("even in the rare case when a breach is established [for a breach of any duty of a charitable fiduciary], under state law, a finding of liability almost never results in a punishment more severe than admonishment or, at worst, removal of the fiduciary.").

97 See A.B.A. MODEl RULE OF PROF'L CONDUCT R. 1.2 ("A lawyer shall not counsel a client to engage, or assist a client, in conduct that the lawyer knows is criminal or fraudulent ... .).

98 RESTATEMENT (THIRD) OF TRUSTS $\S 67 \mathrm{cmt}$. d, at 517. 
It must be admitted, however, that the exception for unilateral action is limited, if not grudging. Most obviously, court approval is permissive, not mandatory, even if the application is what the court itself, on proper petition, would have authorized. The exception gives no direction to courts in granting or withholding approval. Judges could be expected to deal forgivingly with inadvertent failures to seek prior permission on the part of unsophisticated trustees acting in good faith without benefit of counsel, and quite differently with trustees who do not fit that description (not to mention their lawyers).

Furthermore, the zone of comfort is not only ill-defined, but also small. To fit within the exception, the new application of charitable assets must be "such as the court would have directed" (emphasis added). Given that, in any particular case, the court would almost certainly have at least some range of options available to consider, it may never be literally possible to say which specific one it "would have directed." As a practical matter, that target will be even harder to hit if that retrospective finding is to be made by the court itself. And, of course, before the court could consider any particular new purpose, it would logically have had to determine that the donor's original purpose was frustrated. Though that may, in many cases, be true, it is hardly true in our example. Finally, and perhaps most telling, as a practical matter, the Restatement's Reporter cites no authority for this proposition. Unlike gravity, it seems to be, at best, a good idea, but not yet the law.

Quite aside from these limits to the Restatement's exception, there is another problem. So far, we have focused on the concerns of the trustees and their lawyers, those who would be transferring the charitable assets. In cases where some private party has a legally cognizable interest in preventing the transaction, however, the recipients of the assets would also have a problem. They will be loath to purchase at full market price assets that may be subject to collateral, third party claims. As we have seen in several of our examples, Wal-Mart is not going to buy land subject to a forfeiture provision enforceable by a third party. Any such "cloud" on the title is likely to eclipse the deal.

\section{Charities' Acting with State Attorneys General}

Charitable unilateralism, then, is a dubious, if not dangerous, path around dead hand control. To find a safer and surer route, we must note an interesting procedural wrinkle in charitable fiduciary law. Charitable trustees, as we have seen, are bound by duties of care, loyalty, and obedience. Efforts to avoid dead hand control implicate 
only the latter. But to implicate the duty of obedience in theory can usefully be distinguished from invoking that duty in fact. Put another way, departing from donor intent may, as a theoretical matter, violate the duty of obedience. But, as a practical matter, any such violation raises a very real practical problem, literally, a problem of practice: How is the violation to be dealt with? Assuming a substantive violation of the duty of obedience, what is the process for its enforcement?

The answer, even as a matter of doctrine, is surprisingly complicated. All authorities agree that, in all states, the power to enforce charitable trusts rests with the state attorney general and cotrustees. What is much less clear is the extent to which anyone else has legal recourse when the duty of obedience is violated. ${ }^{99}$ The narrowest view of the matter is that this power rests exclusively in the state attorney general and co-trustees. Only slightly broader is the position that, in addition to these, only those with a reversionary interest in the asset in question may sue, in essence to assert that, by changing the use the donor stipulated, the gift to charity is forfeit in their favor. In our example, that would be the position of Northrop and Sutherland as residuary legatees. The broadest position, itself admitting of degrees of breadth, is that beneficiaries with a "special interest" in the trust may sue to prevent changes that somehow adversely affect their interests. ${ }^{100}$ Under this last approach, for example, retired ministers eligible to reside at Aunt Essie's house would be empowered to sue to prevent the Church from selling it to Wal-Mart.

Consistent with the broadest position, beneficiaries of a charitable trust could argue that change in not only use of assets, but also investment of assets, affects their interest, and thus should be subject to their invocation. The special restrictions, they could argue, were in place for their benefit, and so should be subject to their enforcement. Consistent though this argument is with the broader view of beneficiary standing, the latter by no means logically implies the former. Nor would the policy reasons for beneficiary standing be as strong in the case of administrative provisions. Beneficiaries faced with a change in charitable purpose stand to lose real, material

99 See Evelyn Brody, "From the Dead Hand to the Living Dead: The Conundrum of Charitable-Donor Standing", Address at the $17^{\text {th }}$ Annual NYU Conference on Philanthropy and the Law (October 27, 2005); see also Mary Grace Blasco, et al., Standing to Sue in the Charitable Sector, in 4 TOPICS IN PHILANTHROPY 1-15 (1993); Atkinson, Unsettled Standing, supra note 6.

${ }^{100}$ See RESTATEMENT (THIRD) OF TRUSTS $\S 67 \mathrm{cmt}$. d ("institutions and individuals having a special interest in the charitable purpose"). 
benefits; if the soup kitchen is closed, or moved to another slum, its present patrons will go hungry. If, on the other hand, the donor's strong preference for investment in the Campbell Soup company is not indulged, the soup kitchen's beneficiaries are likely to have more money, not less, available for their relief.

What is more, the leading cases for beneficiary standing either involve substantive, not administrative, aspects of dead hand control or, more typically, they involve, not the duty of obedience, but the duty of care or loyalty. Thus, with respect to non-substantive, purely administrative aspects of dead hand control, the prevailing positionperhaps the universal position-is that no one but a state attorney general or a co-trustee has standing to sue for enforcement. If that is so, then, by mutual agreement, the attorney and the trustees, acting unanimously, can effectively thwart enforcement of any administrative form of dead hand control. ${ }^{101}$

This is not to suggest that they could, much less should, exercise this opportunity in an unprincipled way. The operative principle, however, should be maximizing return on investment relative to risk, not honoring donor instincts in that regard. Furthermore, this principle could be - and under the law of some jurisdictions, may be-at least at the outer extremes, subject to beneficiary enforcement. The relevant duty in that case, though, would not be the duty of obedience, but rather the duty of care or loyalty. Neither the trustees nor the state attorney general could, consistently with these other duties, accede to administrative re-arrangements that involved self-dealing or undue risk.

Joint action by charitable trustees and the state attorney general may, accordingly, be an effective means of avoiding administrative forms of dead hand control. What, though, of substantive forms? There are very real opportunities here, too, though the matter is a bit more complicated. For another thing, as we have seen, substantive provisions themselves come in a variety of kinds; they can cover, for example, not only the use to which charitable assets are put, but also who benefits from those uses. Thus, in the case of the Aunt Essie's bequest to the Church, the East Forty is to be used as a retirement residence for the former ministers of a particular Church. More

101 See Sasso, supra note 6, at 1530 ("For as a legal duty, the duty of obedience means little without a corresponding threat of legal sanction, which under the current status of nonprofit law appears extremely unlikely when the law does not empower the individuals who are uniquely qualified to monitor and enforce this particular duty [i.e., charities' chief executive officers]."); see also Goldschmidt, supra note 44, at 632 ("the law plays little role, other than aspirational, in assuring accountability in the nonprofit sector," even as to the fundamental duties of care and loyalty). 
significantly, the judicially-administered doctrine for removing administrative provisions, equitable deviation, is more permissive than cy pres, the comparable doctrine applicable to substantive changes. For state attorneys general and trustees effectively to bar judicial review of substantive changes would, accordingly, be a more radical step.

That said, we should note that this approach, or something remarkably like it, is hardly unprecedented, either in statutory or common law. On the statutory side, the Illinois legislature has recently placed the exercise, not just the invocation, of cy pres power in the state attorney general, upon application by the trustees. The state attorney general's approval of a modification of charitable gifts does not require the additional approval of a court, and it appears to be subject to a more permissive standard of frustration of the gift's original purpose. ${ }^{102}$

On the common law side, the precedent for my proposal is less obvious, but arguably more powerful. The precedent is less obvious, because it appears as an implication of standing doctrine; it may be more powerful, because it gives a state attorney general much more discretion. In a broad category of cases, as we have seen, donors make gifts to charities without explicit restrictions; some courts infer restrictions, others do not. Even the courts that infer restrictions tend to severely limit those with standing to enforce them. In the words of one thoroughly orthodox commentator:

In the absence of special provisions in the trust instrument, neither the settlor nor his successors by will or intestacy may sue to enforce or to obtain a construction of a charitable trust. They are not representatives of the public to be benefited. Nor may they secure a decree that the property be delivered to them when they can prove a violation of the trust. They should bring pressure on the Attorney General. ${ }^{103}$

To see the implication of this limitation on standing, consider its application in the case of Aunt Essie's $\$ 500,000$ bequest to the Church's child care program. Aunt Essie's specific bequest, as we have seen, makes no explicit default provision; if Northrop and Sutherland are to be default takers, it must be through her will's

102760 ILL. COMP. STAT. 55/15.5 (2007).

${ }^{103}$ BOGERT, supra note 39, at 556; see also Trustees of Dartmouth College v. Woodward, 17 U.S. (4 Wheat.) 518,642 (1819) (holding that donors' "descendants may take no interest in the preservation of' funds given to the college). The Model Trust Act is even less generous. Under Section 413 (b), even explicit gifts over to private individuals are valid only within 21 years after the creation of the trust. MODEL TRUST ACT $\S 413(\mathrm{~b})$. 
residuary clause, under an unstated but implicit condition that the bequest continue to be used by the Church for pre-school purposes. Northrop and Sutherland may be entitled to take the $\$ 500,000$ by default, but they cannot sue to enforce that entitlement. Their only recourse, even under current doctrine, seems to be to "bring pressure on the Attorney General."

This result, paradoxical as it may at first appear, is entirely consistent with my proposal. Indeed, it implies that the courts, in restricting the class of those who may seek review of trustees' actions, recognize the wisdom of letting a state attorney general act as a kind of gatekeeper to judicial resolutions. My proposal, if anything, is less, rather than more, radical. For my purposes, it is enough that the residuary takers be denied standing to enforce the duty of obedience; current doctrine seems to preclude their suing to enforce the duties of care and loyalty as well.

There is one final noteworthy feature of the state attorney general's gatekeeping role under the cy pres doctrine: it should asymmetrically favor removal of dead hand control. ${ }^{104}$ If charitable trustees persuade the attorney general not to enforce a particular measure of dead hand control, they have what they want. If, on the other hand, the state attorney general declines their request, the trustees can still seek judicial amendment themselves. In the first case, the trustees are better off; in the second, they are no worse off. The same appears to be true of the state attorney general's statutorily expanded cy pres power in Illinois. ${ }^{105}$

\section{Charities' Buying Out Adverse Private Interests}

Some aspects of dead hand control, we saw in the last section, can be overcome by joint action of the state attorney general and the charity's trustees. This method may apply to substantive as well as administrative provisions. But, with respect to the former, in most if not all jurisdictions, third parties may well have interests that cannot be abrogated without their consent. This last phrase is fundamentally important to our exploration of ways to remove dead hand control. Even if some have interests, typically as either trust beneficiaries or private holders of reversionary, default interests, these can be

104 There is another advantage, perhaps fittingly to be noted sub-textually, if not sub rosa: the relative low visibility of such informal resolutions. See Brody, The Limits of Charity Fiduciary Law, supra note 43, at 1411 ("invisibility at the informal end of the regulation spectrum makes it very difficult to judge the effectiveness of regulators in influencing charity behavior.") (citation omitted).

105760 ILL. COMP. STAT. 55/15.5(f) (2007) ("The provisions of this Section are an alternative to and not in abrogation of any other course of action provided by law."). 
removed in a very old fashioned way: anticipatory settlement of adverse claims or, in a word, purchase.

\section{a. Side Deals With Charitable Beneficiaries}

Consider, first, the interests of trust beneficiaries. As we have seen, Aunt Essie's retirement home for former ministers of Indiantown Presbyterian Church has an identifiable, and small, set of beneficiaries. Depending on what the trustees planned to do with the proceeds of the sale, these beneficiaries would be more or less seriously disadvantaged. If, at the most extreme, the trustees planned to use the proceeds for an entirely different, though still charitable, purpose, the prospective residents of the East Forty retirement home would be left, literally, without a home. At the other extreme, if the trustees planned to take the proceeds and build a new home elsewhere, perhaps even nearby, the prospective residents may be no worse off, and conceivably even better off. In either case, for a greater or lesser price, depending on the circumstances, these beneficiaries may well be willing to trade their interest in having a place in the home at its present location for cash or other consideration-a better living arrangement in a new facility, if there is to be one; if not, maybe a nice condo at Del Boca Vista, Phase II.

Such side deals between charitable trustees and beneficiaries would have the obvious purpose and effect of frustrating the donor's original intent. In that respect, it is worth noting here a very close parallel in the law of private trusts, which is fairly well recognized in the law: removal of dead hand controls by the join action of trustees and beneficiaries.

As we saw in the last Part, substantive law in a majority of American jurisdictions does not give beneficiaries the power to terminate or modify trusts. Thus beneficiaries in the position of Sutherland and his descendents have very little latitude in which to maneuver around the constraints Aunt Essie has imposed on their disposition and enjoyment of trust assets. With very narrow exceptions not likely to be helpful in our hypothetic and many other cases, they cannot compel the trustee, Cousin Northrop, to ignore dead hand constraints Aunt Essie placed on the use and disposition of the farm when she devised it to him in trust. Cousin Northrop, under the duty of obedience, cannot sell the farm to Wal-Mart and distribute or re-invest the proceeds in contravention of Aunt Essie's directives.

As soon as we consider the procedural side of this situation, however, we discover a paradox: The duty of obedience that Sutherland owes Aunt Essie may be, on the one hand, a duty without 
a penalty for him and thus, on the other hand, a right without a remedy for her. If, with the consent of Sutherland and the other trust beneficiaries, Northrop sells the property to Wal-Mart, who is there to object on Aunt Essie's behalf, and how? Aunt Essie herself is, by hypothesis, dead. No other private party has a legally cognizable interest in enforcing the duty of obedience that Northrop nominally owes her.

As the United States Supreme Court noted in dicta almost a century ago, "if the trustees should disregard the time of payment [set in the trust instrument] and pay over to each legatee his or her legacy when they are competent to give a valid discharge, there would be no one who could call them to account."106

Courts themselves might conceivably step into this breach on behalf of the settlor. Indeed, the same Supreme Court opinion intoned, also in dicta, that "there is no higher duty which rests upon a court than to carry out the intentions of a testator when the provision is not repugnant to settled principles of public policy and is otherwise valid." 107 But how would this asserted judicial duty be invoked, and by whom? Many private trusts, particularly testamentary trusts, are subject to continuing judicial supervision. ${ }^{108}$ In those circumstances, trustees must render the supervisory courts periodic accounts, and they must, at the trust's termination, submit a final accounting to that court for their ultimate release from potential liability to disgruntled beneficiaries. An especially circumspect trustee might well suspect that a beneficiary who agreed to the trust's termination might, upon squandering the assets tendered to them, sue the trustee for failing to protect them from themselves, even as the settlor intended. ${ }^{109}$

Such cases have, in fact, arisen, with a fairly consistent result, ${ }^{110}$ which is now ensconced in the Restatement:

If there is a sole beneficiary who is not under an incapacity and the trustee transfers the trust property to him or at his direction, or if there are several beneficiaries none of whom is under an incapacity and the trustee transfers the trust property

${ }^{106}$ Shelton v. King, 229 U.S. 90, 94 (1913).

${ }^{107}$ Id. at 101 .

${ }^{108}$ BOGERT \& BOGERT, THE LAW OF TRUSTS AND TRUSTEES at 241 (rev. $2 \mathrm{~d}$ ed. 1983).

${ }^{109} \mathrm{As}$, in fact, some have. See, e.g., Hagerty v. Clement, 196 So. 330 (1940) (unsuccessful suit by beneficiary under circumstances described in text).

110 RICHIE ET AL., DECEDENTS' ESTATES AND TRUSTS 685, n.22 (setting out basic rule and citing authorities). 
to them or at their direction, the trust terminates although the purposes of the trust have not been fully accomplished. ${ }^{11}$

These arrangements between the trustees and beneficiaries of private trusts are not, of course, precisely comparable to the arrangements I am recommending between charitable fiduciaries and those charitable beneficiaries who have standing to sue to enforce the terms of charitable gifts. The latter, as we have seen, are admittedly affected with a substantially greater public interest, as reflected in the supervisory role of state attorneys general. That distinction, I would maintain, cuts in favor of at least as great a latitude to side deals with the beneficiaries of charities as with the beneficiaries of private trusts. But that argument, whatever its merits, is not the point to be made here. I note the analogous case of private trusts here simply to show that the judicial disregard of settlors' dead hand control is neither as novel nor as unusual as might first appear.

\section{b. Side Deals With Default Takers}

Charitable beneficiaries, as we have seen, are not the only private parties who may have standing to enforce dead hand constraints on charitable assets. The other principal class, for purposes of our analysis, are "default takers," those who stand to receive the assets of charitable trusts that fail. In the case of Aunt Essie's bequests and devises, remember, these would be Northrop and Sutherland, who are the residual beneficiaries of her will. Even jurisdictions that are extremely stingy in granting standing to donors' heirs and residuary legatees are more generous if these default takers hold a more clearly identified interest, such as a reversionary interest in real property. Northrop and Sutherland, for example, are more likely to have standing to assert a reversionary interest in the East Forty than any analogous interest in Aunt Essie's bequest to the Church's kindergarten program, unless she specifically names them as default takers.

Holders of assertable interests of this sort differ from beneficiaries like the retired ministers in the last example in several important respects. First, and most obviously, they have no real incentive to see that the charitable assets in question are used for their original purpose. The retired ministers will get to live in Aunt Essie's house if it is not sold to Wal-Mart; Northrop and Sutherland, on the other hand, stand to gain nothing from the continuation of Aunt Essie's

${ }^{111}$ RESTATEMENT (THIRD) OF TRUSTS $\$ 342$ (Conveyance by Trustee to or at the Direction of the Beneficiary). 
original charitable purpose. They may, to be sure, want nothing more than for her will to be done. But they may, on the other hand, be more than happy to see that will completely frustrated-for the right price. ${ }^{12}$ Second, their asking price for their interest, compared to any given beneficiary's, is likely to be quite high relative to the entire value of the charitable assets in question. This is because, if the charitable purpose fails, the charitable assets default, in total, to them.

The perversity of default takers' motives is clearest when the trustees are faced, not with a change from one viable use of assets to another, but with the failure of the assets in their current use to achieve their charitable purposes. This latter, of course, is precisely the situation where the cy pres doctrine is applicable. In this situation, default takers, be they private or charitable, have a vested interest in seeing that the first condition of the cy pres doctrine is met, but not the second. The first condition, remember, is that the original purpose fail; the second is that the donor have had a general, not just a specific, charitable intent. If both conditions are met, the court will direct the charitable assets to a purpose more or less like the original purpose. Charity wins-at the default takers' expense. On the other hand, if the court finds the original purpose frustrated but fails to find that the donor had a general charitable intent, then just the opposite occurs: charity loses, and the default takers win.

It is important to appreciate this strategic situation, because it may cast important light on the likely motives of many default takers in cy pres situations. For all their asserted concerns about ensuring fidelity to the will of the original donor, they may well be out only to feather their own nests. Those who invoke dead hand control of charitable assets may not have any interest whatsoever in advancing the cause of charity. Rather, they may be invoking the dead hand as a kind of embalmed cat's paw to pull assets out of the helping hands of charity and into hands that are very much alive, and very much selfinterested: their own. To the extent that this is the case, trustees should feel considerably less squeamish about buying off default takers, and state attorneys general should feel less compunction about signing off on such settlements.

Here again, the state attorney general and the trustees could, and should, act in a principled way. The guiding principle, for both,

112 See BOGERT \& BOGERT, THE LAW OF TRUSTS AND TRUSTEES at 62 (rev. 2d ed. 1991) ('In many cases they [donors' heirs] would be either wholly uninterested in exercising the right of visitation, or would be openly hostile to the institution that had deprived them of a part of the fortune of their relative."); see also Goldschmidt, supra note 44, at 652 ("Except in the most unusual circumstances, it is the nonprofit corporation rather than a class or individual that should be the recipient of any monetary recovery [for breach of a charitable fiduciary's duty]."). 
should be how much improvement for charity they are buying with their settlement dollars. Beyond some point, cost will almost certainly exceed any conceivable benefits. Indeed, in this classic example of a bilateral monopoly, strategic behavior on the part of either or both sides of the deal may cause a mutually beneficial trade to fail.

\section{Charities' Invoking Eminent Domain}

To deal with this last hurdle, private parties' holding out for prohibitively high prices, we must approach, with admitted trepidation, a radical solution: invoking the government's power of eminent domain. In this final, admittedly extreme scenario, a governmental body with the power of eminent domain would act as the partner, if not the agent, of charity, forcing the private holdouts to sell their interest in charitable assets at a court-determined price.

To see how this tactic would work, consider, first, a noncharitable, and fairly typical, case. Recall the state of title in the West Forty at Aunt Essie's death. Uncle Wesley had bought from her the underlying fee interest; that interest allowed him, and anyone to whom he transferred his interest, to use the land as a farm, but only as a farm, forever. The power to enforce that restriction to farming use passed, through the residuary clause of Aunt Essie's will, to Northrop and Sutherland. Acting alone or in concert, the two of them could prevent any non-agricultural use of the West Forty. Accordingly, as we saw, they could thwart Uncle Wesley's sale to Wal-Mart, or they could permit that sale, for a "cut" of the sales proceeds.

Suppose, now, that it is not Wal-Mart that wants to buy the West Forty, but the county government. As it happens, the central location of Aunt Essie's original holdings makes that land ideal, not just for a super Wal-Mart, but also for a regional waste disposal facility. Once again, let us assume, Uncle Wesley is more that willing to sell; even if he is not, the county can acquire his possessory interest in the farm by exercising its power of eminent domain. If he sells voluntarily, the price will be what he and the county agree upon; if he were to hold out for a higher price, the county could invoke its power of eminent domain to award him the market value of his interest as "just compensation" under the Fifth Amendment Takings Clause.

What, though, of Northrop and Sutherland's veto over any nonagricultural use? It is important to see that they too, will have to part with their interest-voluntarily, if they and the county can agree on a price; involuntarily, in a condemnation action, if they cannot. If the latter, what will be the required "just compensation?" 
Theoretically, ${ }^{113}$ it should have two components, both of which we have already identified. The first component would be measured by the diminution in value that their neighboring lands, the North Forty and the South Forty, suffer from having a waste dump located nearby. The second component would be measured by the difference between the West Forty as a farm, which value would go to Uncle Wesley, and the value of that land for any other, more valuable, use. As we have seen, it was presumably to protect them against the down-side risk of distasteful non-agricultural uses and to allow them to participate in any up-side gains from non-agricultural uses that Aunt Essie reserved the use restriction in the first place.

With that example in mind, consider, again, the situation with Wal-Mart. Wal-Mart, stymied by Northrop and Sutherland's holding out for higher price to release their anti-development condition, persuades the County to condemn a fee simple absolute interest in the West Forty, either by itself or as part of a larger "commercial park" or "rural renewal zone." 114 What is the value of their "just compensation?" Here, as in the case of the condemnation for the waste facility, it should be the sum of the diminution of value in their neighboring land and the increase above farm-use value of the West Forty itself.

Suppose, now, that Wal-Mart tries this tactic, not with respect to the West Forty, but with respect to the East. As for beneficiaries, just

${ }^{113}$ As a matter of current law, there is considerable uncertainty whether Northrop and Sutherland would receive any compensation at all for their reversionary interest which, as we saw earlier, is a possibility or reverter (or, less likely, a power of termination). In the words of the leading treatise on eminent domain law, "A possibility of reverter is not a compensable property interest that may be paid for as a result of condemnation." JULIUS L. SACKMAN, NichOlS ON EMINENT DOMAIN 12D-80 (3d ed. Supp. 2005) (citation omitted); id. at 5-73 ("whether the estate is regarded as a determinable fee or as subject to a condition subsequent. . . the rights of the grantor, although enforceable if the land ceased to be used for the designated purpose, are not generally considered an estate or interest in land which is compensable upon a public taking.") (citations omitted). A minority of jurisdictions, with the support of the Restatement, divide compensation between the holders of the possessory, fee interest and the reversionary interest if the triggering of the defeasing condition is imminent. Id. at 5-75. In the text I take an even more strongly favorable position toward reversions not only because it seems the better reasoned, but also because, as we shall see, it presents me, in next hypothetical, with a worse-case scenario for my preferred outcome. For a lucid and compelling critique of both the majority and Restatement positions, see Note, Effect of Condemnation Proceedings by Eminent Domain Upon a Possibility of Reverter or Power of Termination, 19 VILL. L. REV. 137 (1973).

114 The current constitutional limits on eminent domain would almost certainly cover the larger projects, if not the smaller. Kelo v. New London, 545 U.S. 469 (2005); $c f$. Fred Guarino, Alabaster Property Owners File Federal Suit, SHELBY COUNTY REPORTER, Sept. 10, 2003, available at, http://www.shelbycountyreporter.com/articles/2003/09/10/news/news04.txt and Fred Guarino, Eminent Domain Settlement Reached-Eight of 10 Landowners Agree to Sell, Jan. 6, 2004, available at, http://www.shelbycountyreporter.com/articles/2004/01/08/news/news04.txt (filing and settlement of homeowners' suit in opposition to local government's exercise of eminent domain to acquire land for a mixed-use project that included a Wal-Mart Supercenter). 
compensation should be fairly easy. In the case of the retired ministers, it would be comparable quarters elsewhere, perhaps with a bit of a premium for the hassle of having to move house. In any case, it need not be the condo in Del Boca Vista that they were holding out for before the County stepped in. In the case of the Church members with the right to use the East Forty as a park, the compensation would be, at most, a comparable open space elsewhere, perhaps enhanced by greater amenities to compensate for any lesser convenience of the new location.

Just compensation to Sutherland and Northrop, by contrast, is a bit more complicated. To understand why this is so, we must first recall what their interest actually is, and why they have it. They are entitled to the entire interest in the East Forty, if, but only if, two conditions are both met: first, if the East Forty is not used for the purposes Aunt Essie stated in her will, and, second, if she also had no general charitable intent. If both these conditions are met, the doctrine of cy pres would apply, and a court would almost certainly permit the sale proceeds from the East Forty to be used for other charitable purposes more or less close to what Aunt Essie originally had in mind. If the eminent domain action makes the original charitable purpose impossible, and if a court finds general charitable intent on the part of the original donor, then the value of the "lost" residuary interest is, in effect, zero.

But what if the court were to find no general charitable intent? Then the gift of the East Forty to the Church would fail, and Northrop and Sutherland would take the East Forty by default. What we have to determine, then, is the value of this prospect. The three logical possibilities are all of the value of that parcel, or none, or somewhere in between. And these are, in fact, the courses the courts have taken. $^{115}$

"All" and "none" both seem wrong. All seems too much, because it requires the state, in effect, to double compensate: first the Church, for the fee simple determinable, then Sutherland and Northrop, for the "triggered" right to get the fee simple absolute back when the change occurs. On the other hand, "none" seems too little. But for the condemnation, Northrop and Sutherland did have some prospect of getting the entire parcel. ${ }^{116}$

${ }^{115}$ See Victor P. Goldberg, et al., Bargaining in the Shadow of Eminent Domain: Valuing and Apportioning Condemnation Awards Between Landlord and Tenant, 34 U.C.L.A. L. REV. 1083, 1133-34 (1987) (noting that: a majority of courts award all to the fee holder, which they, favor as a default rule; a minority award all to the default taker; and at least one court apportions the award between the two.). See also note 119, supra.

${ }^{116}$ This situation would also seem to present a serious moral hazard problem. The 
If only by elimination of the other logical alternatives, then, something in between all and none of the value of the East Forty must be the right compensation for Northrop and Sutherland's reversionary interest. But where, in the wide range between all and none, should a court set the compensation? Here Northrop and Sutherland may themselves have given us a helpful, if inadvertent, hint. In all likelihood, they and others in their position, or their professional advisors, will have already assigned a value to reversionary interests like these. Unfortunately for the holders of such interests, that value is likely to have been zero or its very near approximation.

Here is why. In filing Aunt Essie's federal estate tax return, the lawyers for her personal representative will almost certainly have claimed a charitable deduction for her bequest of the East Forty to the Church. To qualify for that deduction, ${ }^{117}$ and for the analogous income ${ }^{118}$ and gift tax deductions, ${ }^{119}$ the gift must, with limited exceptions, be of a full interest in the asset in question. If, as with the East Forty, there is a default provision, the prospect of its coming into effect must be negligible. Thus private parties in Northrop and Sutherland's position have a double incentive to state low values for their reversionary interests: first, to ensure that the gift to charity meets the requirement that any likelihood of defeasance be de minimis and, second, to ensure that the value of the condition reduces the value of the charitable deduction by as little as possible.

It hardly seems unfair to hold potential default takers like Northrop and Sutherland, in an eminent domain proceeding, to valuations they themselves elected in another proceeding where the value of the very same interest was at issue. On that reasoning, the Church and similarly-situated charities, as holders of the present interest, should receive virtually all of the proceeds from the sale of the underlying asset. Their share should be the fair market value of the asset in the

government would, by its own action, trigger an otherwise unlikely or uncertain event, the change in land use, without having to take into account its full cost. That risk, however, is reduced to precisely the extent that any reduction in the price paid to holders of future interests is offset by an increase in the price paid to holders of the possessory, fee interest.

11726 C.F.R. $\$ 20.2055-2$ (b)(1).

11826 C.F.R. \& 1.170A-1(e) ("If an interest in property passes to, or is vested in, charity on the date of the gift and the interest would be defeated by the subsequent performance of some act or the happening of some event, the possibility of occurrence of which appears on the date of the gift to be so remote as to be negligible, the deduction is allowed."). For example, A transfers land to a city govemment for so long as the land is used by the city for a public park. If on the date of the gift the city does plan to use the land for a park and the possibility that the city will not use the land for a public park is so remote as to be negligible, $A$ is entitled to a deduction under section 170 for his charitable contribution.

11926 C.F.R. $\$ 25.2522($ c) $-3($ b)(1). 
highest valued use, less the negligible amount attributable to default takers' remote prospect of getting the asset back by forfeiture.

This example does, admittedly, press the outer edge of current eminent domain law. In fact, it may well be that the United States Supreme Court would not countenance as naked a forced transfer from one private landowner to another as I have imagined in the cases of the Aunt Essie's West and East Forties and Wal-Mart. The dissenting justices in the recent Kelo case list such examples as reductions ad absurdum, ${ }^{120}$ and the majority opinion strongly suggests that they would be beyond the pale. ${ }^{121}$ I myself am inclined to hope, if not entirely believe, that my Wal-Mart scenarios would fail for lack of requisite public use.

For our purposes here, though, it is important to see that a wide range of much more significant transfers might well qualify for the exercise of eminent domain. Suppose that it is not Wal-Mart who wants the East Forty, but Hospital Corporation of America. Operating a hospital is not only a paradigmatic charitable purpose, but also the kind of public use that falls easily within the narrowest parameters of the relevant constitutional restrictions on the exercise of eminent domain. Almost without question, the Church could, consistently with the federal takings clause, enlist a local government to condemn the East Forty for use by a hospital, whether the hospital be charitable, public, or for-profit.

This reasoning should apply to any switch of real estate from one charitable use to another charitable use, where the real estate was to be used for a public purpose like a park or school. Even that expansion, however, would leave a great many of charitable assets locked in their current use. Most charitable assets, like most other assets in a modern, non-agrarian economy, are not in the form of real estate, but rather in the form of intangible, paper assets.

In the face of that serious limitation, eminent domain law does offer us one final possibility of extrapolation. That is, for our purposes, the ultimate frontier: taking any particular reversionary interest in charitable assets to permit the use of those assets for a different, but still charitable, use. To see how this final extrapolation would work, we need to look at it from both sides, first as to the private property being taken, then as to the public use being served. With respect to the former, eminent domain is currently said to be

${ }^{120}$ See Kelo v. New London, 545 U.S. 469, 503 (2005) (O'Connor, J., diss.) ("Nothing is to prevent the State from replacing any Motel 6 with a Ritz-Carlton, any home with a shopping mall, or any farm with a factory.").

${ }^{121}$ See Kelo, 545 U.S. at 487 ("Such a one-to-one transfer of property, executed outside the confines of an integrated development plan, is not presented in this case."). 
deployable to take any form of private property. ${ }^{122}$ As we have seen, reversionary interests in determinable fee interests in land clearly qualify as private property for eminent domain purposes; there is no reason, in principle, why eminent domain could not be applied to reversionary interests in intangible personal property as well. ${ }^{123}$ In the final analysis, indeed, all property interests are equally intangible; even with respect to land, what one holds is an estate in land, one or more metaphorical twigs in the proverbial bundle of legally protected interests with respect to land, not the land itself. One could, accordingly, single out for condemnation precisely that twig with respect to charitable assets that allows a private party to hold them in a particular charitable use upon pain of forfeiture. As we have seen, even if taking such an interest requires compensation-a matter that is by no means assured, even with respect to reversionary interests in realty-the required compensation should arguably reflect a very deep discount.

What about the other side of the coin, the public use to which any such condemned private property would be put? At the most basic level, all charitable assets are held, essentially, for the public benefit. ${ }^{124}$ Current takings law seems clearly to be moving toward an equating of the Fifth Amendment's public use requirement with the public purpose standard of police power regulation, with which the public benefit standard of charity overlaps substantially, in practice as well as in theory. Indeed, it is hard to imagine a charitable purpose that could not be undertaken by the government as a legitimate state interest, with the sole-though significant-exception of the promotion of religion.

This last extrapolation is admittedly a very long stretch; it may well strike many as an egregious bootstrap. It would, in effect, harness a very aggressive version of eminent domain law to plow our way around the traditional law of cy pres. That prospect raises two

${ }^{122}$ See Palm Beach County v. Cove Club Investors Ltd., 734 So. 2d 379 (Fla. 1999) (all property within the state, both real and personal, tangible and intangible, is subject to the government's exercise of eminent domain).

As one who shares the expansive modern view of property, I need to add to this sentence a critical qualifier: "subject to other legal constraints." Without going into unnecessary detail, I can give a sufficient sense of what I mean to exclude with a simple example: the proverbial pound of flesh nearest your heart. Although the state might condemn it as private property, other provisions of the Fifth Amendment Due Process Clause would preclude any taking of that particular piece of tangible personality without a good deal more than the proffer of its fair market value.

${ }^{123}$ See Goldberg, et al., supra 115 , at 1125 (noting that "the government rarely condemns contractual rights," but arguing that, when it does, the same tripartite relationships exists as in the case of land subject to both present and future interests).

${ }^{124}$ Bob Jones Univ. v. United States, 461 U.S. 574 (1983). 
theoretical problems, both of which are answerable, and one practical problem which, in its very nature, is more troubling.

Saving the worst for last, let's look first at the two theoretical problems. It might be objected, first, that the expanded use of eminent domain that I recommend here merely elevates form over substance. On this view, what my proposal would accomplish is simply the elimination of dead hand control under a readily recognizable, if not disingenuous, guise. In response to this objection, we must note two non-trivial differences between the two. For one thing, the abolition of dead hand control would leave entirely in the hands of charitable fiduciaries all decisions about the redirection of charitable assets within the outer boundaries of charity itself. The expansion of eminent domain would allow the same scope for redirecting charitable resources. But responsibility for that redirection would not be exercisable by charitable fiduciaries without the direct involvement of public bodies with the power of eminent domain.

And there is another significant way that expansion of eminent domain would differ from outright abolition of dead hand control. Abolition would work once and for all and across the board. If dead hand control were abolished outright, the governing body of any charity, at any time, could redirect the charity's assets. By contrast, expansion of eminent domain would work piecemeal, case-by-case, one charity at a time. This, together with the need persuade a public body of the merits of any particular change of charitable use, distinguishes the expansion of eminent domain from the abolition of dead hand control in function as well as in form.

That said, it must still be admitted that my proposal has the distinct air of artifice about it. It is, undeniably, a recommendation that we radically truncate one doctrine, cy pres, by drastically expanding another, eminent domain. If the one is not reducible without remainder to the other, it is a lot more like it than what we have now. To that objection there is but one answer, but it is, I think, the dispositive answer. Displacing outmoded doctrine by the manipulation of that very doctrine, or another, is precisely what the best of common law judges have always done. That self-conscious judicial pruning, grafting, and transplanting of precedent is to the evolution of the common law precisely what random mutation is to the evolution of life itself. It is no objection to say that the old law is being bent out of its accustomed, inherited shape; the only legitimate objection is that it is being forged into an inferior new shape.

The second theoretical objection to expanding eminent domain along the lines I suggest is closely related to the first objection. If the 
first accuses me of a change that is more formal than substantive, the second accuses me of irregularities in the process by which this change is to be achieved. As I noted at the outset, I have elsewhere made the case for law's new shape; on the substantive merits of my proposal to end dead hand control of charitable assets, I can only invoke what I have already said. As a matter of process, though, there is something more to be said; there is, in other words, more to say about the way I propose to get at my substantively superior legal result. Even those who like my proposal on the merits, who favor the radical reduction of dead hand control, might dislike the means I've chosen to go about it. The common law, they might object, must play a subordinate role in the age of statutes; rather like today's tortoises, today's courts must be the humble, subordinate relic of noble but extinct ancestors.

Precisely what the role of courts should be in modern democracies is, of course, a larger question than we can cover here. But, with respect to the particular role of courts in the case before us, two points bear noting. First, this case involves the intersection of two bodies of law in which the role of courts has been traditionally large: protecting the interest of charity and promoting the transferability of social assets. Second, the role I would have the courts play in this case is a distinctly subordinate role, even as the means of avoiding dead hand control that I recommend here is a distinctly second-best solution to the problem. As I said in Part I, I invoke judicial action in support of these piecemeal measures because more direct and radical approaches are, on account of collective action problems, not likely to be realized by more direct, politically appropriate means.

This brings us to the third objection, which is more practical than theoretical, and less readily dismissed. In introducing the prospect of using eminent domain to free charitable assets from dead hand control, I sounded a note of caution: here we are deploying a profoundly disruptive governmental power against charitably inclined private donors. Here defenders of charitable autonomy face something of a dilemma: to liberate their assets from private, dead hand control, they would be invoking a politically sensitive, if not suspect, governmental power. Having made my choice, and defended it, let me end this section by admitting a measure of ambivalence: forced to a choice between dead amassers of great wealth and living public officials with public accountability, I choose the latter. But I do not mean to ignore either the public spirit of those I would oppose or the private interest of those with whom I would be allied. With those 
reservations in mind, let us turn from principled practice to its opposite.

\section{B. Unprincipled Practice}

In the last section, we saw how conscientious charitable fiduciaries, acting unilaterally or in collaboration with state attorneys general or entities with eminent domain power, could employ existing legal doctrines in unorthodox ways to bypass dead hand control of charitable assets. In each case, we assumed that these agentscharitable fiduciaries, state attorneys general, and eminent domain authorities-were acting in principled ways. In this section, we must remove that assumption-even as, in practice, each of our suggested agents of reform manifestly has done.

\section{Self-Indulgent Charitable Fiduciaries}

Unprincipled practice on the part of charitable fiduciaries would seem, from my perspective, to be paradoxical, if not impossible. With respect to the duty of obedience, remember, I am a strict abolitionist; I want the decisions of present charitable fiduciaries always to override dead hand control, as a matter of law. As a general proposition, that is, I favor charitable autonomy over dead hand control. On that premise, how could a charitable fiduciary ever act against principle in overriding donor control?

The answer lies in the distinction, long drawn in ethics, both legal and general, between the value of autonomy, on the one hand, and the moral merit of any particular exercise of autonomy, on the other. ${ }^{125}$ Thus, quite consistent with a radically protectionist view of the First Amendment, one can defend Larry Flint's publication of Hustler against state censorship, even as one abhors both the man and the magazine. Similarly, under my view of dead hand control, one can argue that charitable fiduciaries should always be free to override the dead hand, even as one insists that they should only use that freedom to move charitable assets into uses that they themselves conscientiously believe are more likely to advance the public good. They should not, by contrast, use that freedom to advance projects that indulge their private vanities or inflate their egos, even if those projects are well within the legal bounds of charity; a fortiori, they should not choose projects that redound to their personal benefit, even if such benefits do not violate the technical limits of the duty of

${ }^{125}$ See DAVID LUBAN, LAWYERS AND JuSTICE 161-62, 166-67 (1988). 
loyalty. ${ }^{126}$ If they do, they are, in my terms, engaging in unprincipled practice.

\section{Imperialist State Attorneys General}

State attorneys general, we have seen, could frequently remove dead hand controls in particular cases by the simple expedient of assuring charitable fiduciaries that they would not enforce the controls in those cases. The principled reason for declining to enforce the duty of obedience is, in general, the superiority of charitable autonomy to dead hand control and, in particular cases, the direction of charitable assets into more publicly beneficial uses.

It is quite possible, however, that state attorneys general may act in ways that are radically opposed to these principles. As Prof. Brody has observed, "AG" may stand for "aspiring governor" as well as for "attorney general." 27 Politically ambitious state attorneys general might, for example, agree to give their blessing to particular departures from dead hand donor control, but only on condition that they themselves be given a measure of control of their own. ${ }^{128}$ They might, as a matter of substance, insist on approving any change that the charitable fiduciaries plan to make; they might, as a matter of process, insist on appointing the fiduciaries, who would then presumably act to advance the state attorney general's view of appropriate charitable ends. ${ }^{129}$ Either course, the substantive or the

${ }^{126}$ See Brody, The Limits of Charity Fiduciary Law, supra note 43, at 1470-71 ("Some also suspect conflicts on the part of nonprofit trustees and officers, who might receive positions either in the new hospital management or in the resulting foundation.") (citations omitted); Goldschmidt, supra note 44 , at 649,651 ("Subtle conflicts or 'taints' to the process, which might be considered marginal in the for-profit context, should be resolved in favor of duty of loyalty (not business judgment) treatment in the nonprofit conversion context.") Silk, supra note 3, at 747 (In the typical conversion of a nonprofit hospital into a for-profit, "if the board of directors of the converted nonprofit corporation is dominated by members of the for-profit board, they may shape grant making policies to improve the business environment for the related for-profit or to create a disadvantage for competing businesses.").

${ }^{127}$ Brody, Whose Public? Parochialism and Paternalism in Charity Law Enforcement, supra note 80 , at 946.

${ }^{128}$ See Boisture \& Varley, supra note 4, at 232 ("The clear legal authority of state attomeys general to bring suits against nonprofit hospital directors who proceed with a sale or joint venture transaction without court approval—combined with the parties' presumptive desire to avoid a prolonged legal challenge - translates into substantial leverage for the attorney general to require that the parties submit proposed transactions for advanced review and approval and to impose a variety of requirements as conditions for granting that approval.").

129 These are not, alas, purely hypothetical cases. For a thorough, and thoroughly depressing, review of recent abuses by state attorneys general, see Brody, Whose Public? Parochialism and Paternalism in Charity Law Enforcement, supra note 80; see also Mark Sidel, Law, Philanthropy, and Social Class: Variance Power and the Battle for American Giving, 36 U.C. DAVIS L. REV. 1145, 1181 (2003) (noting tendency of state executive branch officials to narrow the scope of the variance power, under which charities reserve the power to amend charitable gifts without recourse to the courts). This is not to suggest, on the other hand, that all 
procedural, would probably be consistent with our most basic principle, obeying the letter of the law. But both would be in direct contravention of another principle, the general preference for independence of charity from governmental direction, as opposed to oversight. In other words, obedience to dead donors would come at the cost of obedience to living state attorneys general or their handpicked surrogates.

\section{Piratical State Legislatures}

Unprincipled though the practices we have considered so far certainly are, they fade almost into insignificant, as a matter of both theory and practice, against the glare of a final form of abuse. Faced with chronic budgetary shortfalls, frequently the result of serious structural inequities in their fiscal systems, several state legislatures have succumbed, understandably, if not quite forgivably, to a terrible temptation: taking large accumulations of charitable assets by legislative fiat. Health care is the most fertile field for this kind of looting; the example of the state of New York is perhaps the most egregious.

Others have, in considerable detail, pointed out the fundamental problems here: serious erosion of the independence of charitable organizations and severe pressure on basic constitutional protections of private property. ${ }^{130} \mathrm{We}$ need not review those compelling critiques here. For our purposes, though, we do need to distinguish such measures from those recommended here. In the first place, though these measures remove the dead hand in that they release assets from their original use, they do not free them for alternative uses by their charitable fiduciaries. Instead, they remove the assets from the charitable sector altogether, placing them in the hands of state agents

conditions placed on charitable conversions by attomeys general serve strictly their personal interest or private ambitions; see also Boisture \& Varley, State Attorneys, supra note 4, at 233 ("In addition to ensuring that the nonprofit entity receiving the sales proceeds is neither influenced nor controlled by the for-profit purchaser, the regulator may also find it appropriate to limit, both by number and length of service, the participation on the board of the successor nonprofit of persons who were involved in negotiating the sale transaction."). See also, Jonathan Klick \& Robert H. Sitkoff, Agency Costs, Charitable Trusts, and Corporate Control: Evidence from Hershey's Kiss-Off, 108 COLUM. L. REV. (forthcoming May, 2008).

${ }^{130}$ See Horowitz \& Fremont-Smith, The Common Law Power of the Legislature, supra note 3; see also Brody, Whose Public? Parochialism and Paternalism in Charity Law Enforcement, supra note 80; see also Brody, The Limits of Charity Fiduciary Law, supra note 43 , at 1501 ("the recent wave of nonprofit hospital sales statutes moves the control of these charities too far from the private discretion of hospital directors and invites too much political risk in the determination of how best to use those assets.") (citation omitted). 
or agencies. This is, then, not so much a removal of dead hand, donor control as it is an imposition of outright state ownership.

In the second place, and more shockingly, in these arrangements the conversion of assets from charitable to public ownership and control is uncompensated. Nothing could be further from my recommendation that charitable fiduciaries sometimes employ the government's power of eminent domain. On the one hand, that use of eminent domain would remove assets from private, not charitable, hands. On the other, essential to the operation of eminent domain is payment of just compensation, at the market value, for the asset taken. Let me end as Prof. Brody begins; bluntly put, "Assets of nonprofit organizations are not governmental assets."131

\section{Summary}

The Low Road recommended here is, in one important respect, decidedly the second best approach to removing dead hand control. It is a bypass that leaves the essential structure of dead hand control largely intact; wholesale, High Road reform would either sweep those barriers entirely away or, at the very least, narrow them more noticeably. In the Low Road's very limits, however, lies something of an advantage. Those who would take this humbler, less ambitious route need not await favorable conditions in the legislatures or appellate courts; the route of principled practice is ready, right now, for those who would move at least some measure of charitable assets from dead hand control to freer management by living trustees. For many charities, much of the time, that may well be enough.

\section{CONCLUSION}

My epigraph, "Ye tak' the high road and I'll tak' the low road, and I'll get to Scotland afore ye," may call to mind a very different take on that nostalgic destination. According to Dr. Johnson, "The noblest prospect which a Scotchman ever sees is the high-road that leads him to England." "132 So far as I know, no one else has quite joined my quest for a charitable realm scot-free ${ }^{133}$ of donor control. On the other hand, no one seems to be urging us in the opposite direction, back

${ }^{131}$ Brody, Whose Public? Parochialism and Paternalism in Charity Law Enforcement, supra note 80 , at 938 .

132 JAMES BOSWELL, 1 THE LIFE OF SAMUEL JOHNSON $§ 1763$.

133 Using "scot-free" in this context implies a measure of ethnic specificity that the term's proper etymology cannot sustain. "Scot" apparently referred originally to a debt, tax, or other obligation, not to people or institutions of Scottish extraction. See CHARLES EARL FUNK, 2107 CURIOUS WORD ORIGINS, SAYINGS \& EXPRESSIONS 40, 615 (1993). 
toward the English common law tradition of greater dead hand control. In that respect, to a greater or lesser extent, everyone who has seriously and conscientiously considered the proper course of charity law seems to be headed in the same direction, toward a future legal regime in which the dead hand holds lighter and narrower sway. Whether by the High Road or the Low, may we get there securelyand soon. 


\section{AUNT ESSIE'S FARM}

\section{Indiantown}

$\uparrow$ Columbia

South Carolina

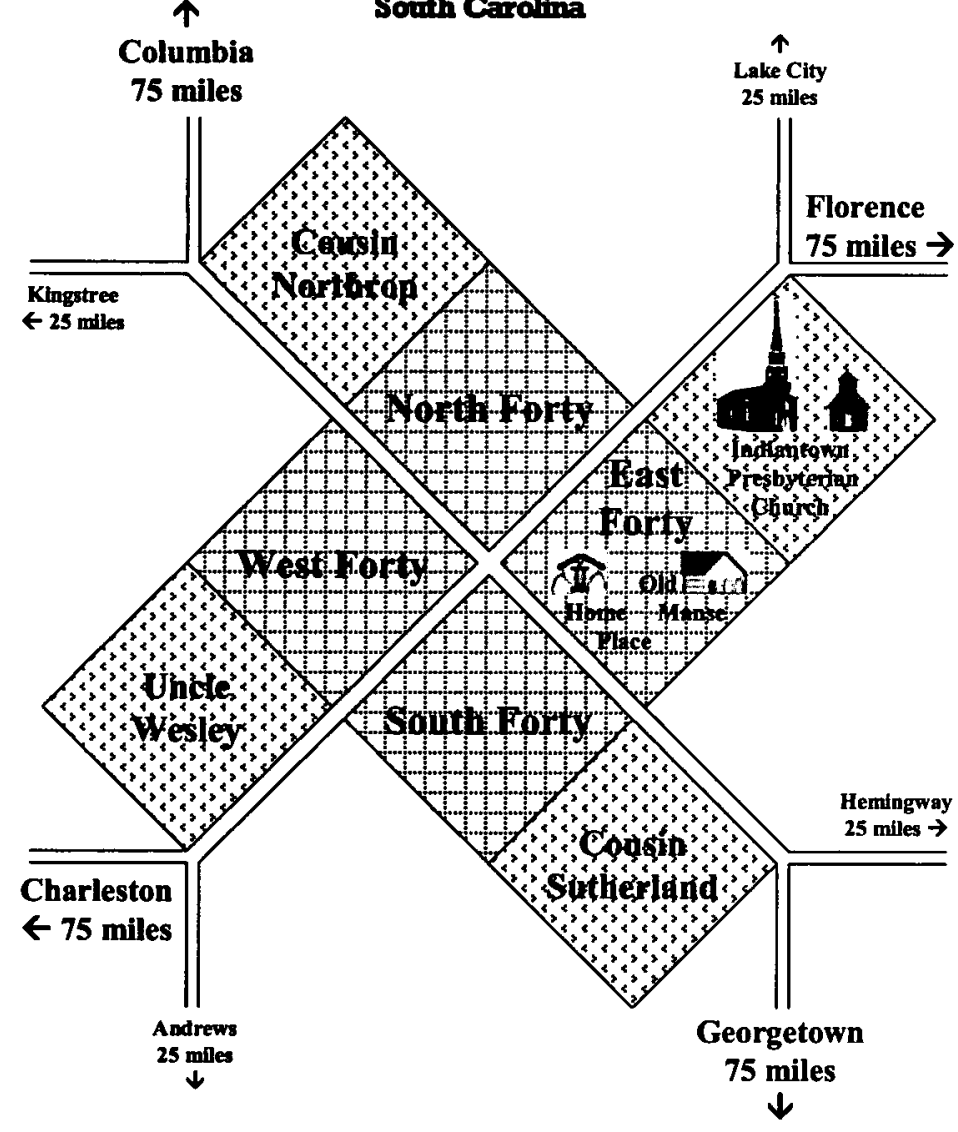

